\title{
Structural Variability in Multifunctional Metal Xylenediaminetetraphosphonate Hybrids
}

Rosario M. P. Colodrero, ${ }^{\perp}$ Giasemi K. Angeli, ${ }^{*}$ Montse Bazaga-Garcia, ${ }^{\perp}$ Pascual Olivera-Pastor, ${ }^{\perp}$ Didier Villemin, ${ }^{\S}$ Enrique R. Losilla, ${ }^{\perp}$ Estefania Q. Martos, ${ }^{\perp}$ Gary B. Hix, ${ }^{\dagger}$ Miguel A. G. Aranda, ${ }^{\perp, \pm}$ Konstantinos D. Demadis, ${ }^{*, \#}$ and Aurelio Cabeza ${ }^{*, \perp}$

${ }^{\perp}$ Departamento de Química Inorgánica, Universidad de Málaga, Campus Teatinos s/n, 29071-Málaga, Spain

${ }^{\#}$ Crystal Engineering Growth \& Design Laboratory, Department of Chemistry, University of Crete, Voutes Campus, Crete, GR-71003, Greece

${ }^{\S}$ Laboratoire de Chimie Moléculaire et Thioorganique, UMR CNRS 6507, INC3M, FR 3038, ENSICAEN and Université de Caen, Caen, France

${ }^{\dagger}$ School of Science and Technology, Nottingham Trent University, Clifton Lane, Nottingham, NG11 8NS, United Kingdom

${ }^{ \pm}$CELLS-ALBA synchrotron, Carretera BP 1413, Km. 3.3, E-08290 Cerdanyola, Barcelona, Spain

Supporting Information

ABSTRACT: Two new families of divalent metal hybrid derivatives from the aromatic tetraphosphonic acids 1,4- and 1,3-bis (aminomethyl) benzene- $N, N^{\prime}$-bis (methylenephosphonic acid), $\left(\mathrm{H}_{2} \mathrm{O}_{3} \mathrm{PCH}_{2}\right)_{2}-\mathrm{N}-\mathrm{CH}_{2} \mathrm{C}_{6} \mathrm{H}_{4} \mathrm{CH}_{2}-\mathrm{N}\left(\mathrm{CH}_{2} \mathrm{PO}_{3} \mathrm{H}_{2}\right)_{2}$ (designated herein as $\boldsymbol{p}-\mathbf{H}_{8} \mathrm{~L}$ and $\boldsymbol{m}-\mathbf{H}_{8} \mathrm{~L}$ ) have been synthesized by crystallization at room temperature and hydrothermal conditions. The crystal structures of $\mathrm{M}\left[\left(\mathrm{HO}_{3} \mathrm{PCH}_{2}\right)_{2} \mathrm{~N}(\mathrm{H})\right.$ $\left.\mathrm{CH}_{2} \mathrm{C}_{6} \mathrm{H}_{4} \mathrm{CH}_{2} \mathrm{~N}(\mathrm{H})\left(\mathrm{CH}_{2} \mathrm{PO}_{3} \mathrm{H}\right)_{2}\left(\mathrm{H}_{2} \mathrm{O}\right)_{2}\right] \cdot 2 \mathrm{H}_{2} \mathrm{O}(\mathrm{M}=\mathrm{Mg}$, Co, and $\mathrm{Zn}), \mathbf{M}-\left(\boldsymbol{p}-\mathbf{H}_{6} \mathrm{~L}\right)$, and $\mathrm{M}\left[\left(\mathrm{HO}_{3} \mathrm{PCH}_{2}\right)_{2} \mathrm{~N}(\mathrm{H})-\right.$ $\left.\mathrm{CH}_{2} \mathrm{C}_{6} \mathrm{H}_{4} \mathrm{CH}_{2} \mathrm{~N}(\mathrm{H})\left(\mathrm{CH}_{2} \mathrm{PO}_{3} \mathrm{H}\right)_{2}\right] \cdot n \mathrm{H}_{2} \mathrm{O}(\mathrm{M}=\mathrm{Ca}, \mathrm{Mg}$, Co, and $\mathrm{Zn}$ and $n=1-1.5), \mathbf{M}-\left(m-\mathrm{H}_{6} \mathrm{~L}\right)$, were solved $\mathrm{ab}$ initio by synchrotron powder diffraction data using the direct methods and subsequently refined using the Rietveld method. The crystal

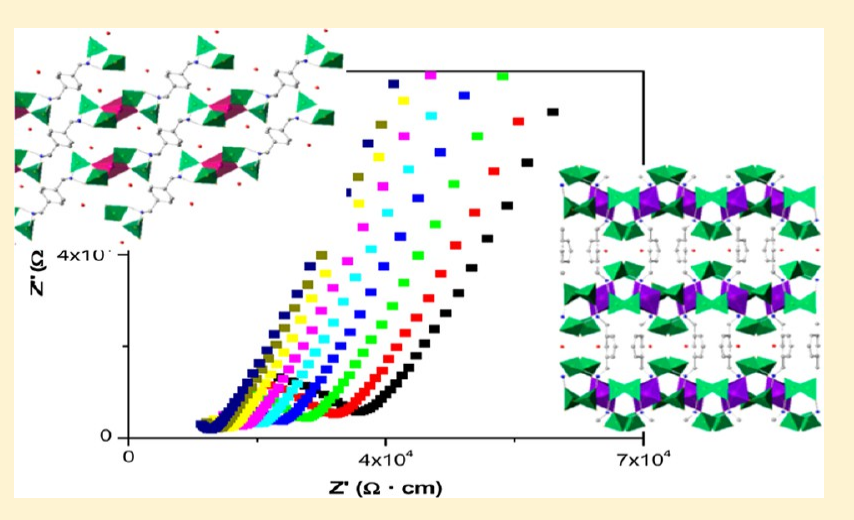
structure of the isostructural $\mathbf{M}-\left(p-\mathbf{H}_{6} \mathrm{~L}\right)$ is constituted by organic-inorganic monodimensional chains where the phosphonate moiety acts as a bidentate chelating ligand bridging two metal octahedra. $\mathbf{M}-\left(m-\mathbf{H}_{6} \mathbf{L}\right)$ compounds exhibit a 3D pillared open-framework with small $1 \mathrm{D}$ channels filled with water molecules. These channels are formed by the pillaring action of the organic ligand connecting adjacent layers through the phosphonate oxygens. Thermogravimetric and X-ray thermodiffraction analyses of $\mathbf{M}-\left(\boldsymbol{p}-\mathbf{H}_{6} \mathbf{L}\right)$ showed that the integrity of their crystalline structures is maintained up to $470 \mathrm{~K}$, without significant reduction of water content, while thermal decomposition takes place above $580 \mathrm{~K}$. The utility of $\mathbf{M}-\left(p-\mathrm{H}_{6} \mathrm{~L}\right)(\mathrm{M}=\mathrm{Mg}$ and $\mathrm{Zn})$ hybrid materials in corrosion protection was investigated in acidic aqueous solutions. In addition, the impedance data indicate both families of compounds display similar proton conductivities $\left(\sigma \sim 9.4 \times 10^{-5} \mathrm{~S} \cdot \mathrm{cm}^{-1}\right.$, at $98 \% \mathrm{RH}$ and $\left.297 \mathrm{~K}\right)$, although different proton transfer mechanisms are involved.

\section{INTRODUCTION}

The quest for new materials with interesting applications is the driving force for the explosion in the field of coordination polymers and metal-organic frameworks. There is substantial momentum in efforts from numerous research groups around the globe that develop in three major axes: (a) easy, reproducible, and scalable syntheses, (b) new structure types, and (c) new applications in everyday life, together with technology transfer in real industrial settings. There is a plethora of good examples in the primary and secondary literature, with several themed issues on the subject (syntheses-structures-applications) ${ }^{1}$ of metal-organic framework (MOF) type hybrid materials, as well as monographs and books.
The two cornerstones in the field of MOFs are secondary building units (SBU's or "bricks") and the organic linkers. There is an impressive number of new SBU's and new (functionalized in so many ways) organic linkers/ligands, thus creating an almost infinite number of reactant combinations. We have been interested in the syntheses, structural characterization, and exploitation of various properties of phosphonatebased MOFs. ${ }^{3}$ In the area of MOFs that incorporate a phosphonate linker, developing the concept of "isoreticular" chemistry is a challenge; however, there are some examples of

Received: April 17, 2013

Published: July 24, 2013 
metal phosphonates that exhibit interesting, systematically evolved structural features. ${ }^{4,5}$

The structural tunability of crystalline MOFs coupled, when possible, with high chemical and thermal robustness, makes them suitable materials to correlate structure with function. ${ }^{2,5}$ Hence, the research focus has been set recently to the potential applications of some of these compounds, including phosphonate-based MOFs, as proton-conducting materials alternative to Nafion and related polymers. ${ }^{3 a, 6}$ These hybrid materials may offer unique proton transfer pathways in the framework of an impressive structural diversity, from $1 \mathrm{D}$ to $3 \mathrm{D}$ supramolecular networks. In this sense, tailored design of the metal linker molecules, control of the basic structural properties and dimensionality, combined with effective synthetic strategies, such as isomorphous replacements ${ }^{7}$ and controlled-aid impregnation of $\mathrm{MOFs}^{8}$ may be applied to obtain/improve proton conductivity in MOFs and polymeric materials.

On a different note, phosphonate additives, initially applied as replacements for carcinogenic chromate in metallic corrosion protection, have since then found extensive use. ${ }^{9}$ There is a consensus in literature reports on a synergistic action of dissolved $\mathrm{M}^{2+}$ and phosphonate ligands that has been assigned to formation of metal-phosphonate inhibiting films on the metallic surface. ${ }^{10} \mathrm{We}$ are continuing a systematic effort to study metal-phosphonate films on metal surfaces, focusing on their accurate description at the molecular level, wherever possible. Within this framework, we studied the inhibitory effects of the aforementioned hybrids on the anticorrosion protection of carbon steel surfaces.

In addition, the metal-phosphonate hybrid materials provide new opportunities for developing multifunctional solids capable of being applied in different ways. One of such application is their use as luminescent materials. ${ }^{11}$ Although the lanthanide phosphonates may be apparently the best candidates, other transition metal phosphonates have been reported to exhibit promising luminescent properties. Furthermore, fine-tuning of the characteristics of the organic linker may play an important role in determining the desired properties. Thus, in this paper, we report two families of isostructural divalent $(\mathrm{Ca}, \mathrm{Mg}$, Co, $\mathrm{Zn}$ ) hybrid phosphonate MOFs based on the tetraphosphonate ligands 1,4- and 1,3-bis (aminomethyl)benzene- $N, N^{\prime}$-bis (methylenephosphonic acid), $\left(\mathrm{H}_{2} \mathrm{O}_{3} \mathrm{PCH}_{2}\right)_{2}-\mathrm{N}-\mathrm{CH}_{2} \mathrm{C}_{6} \mathrm{H}_{4} \mathrm{CH}_{2}-\mathrm{N}$ $\left(\mathrm{CH}_{2} \mathrm{PO}_{3} \mathrm{H}_{2}\right)_{2}$, (designated herein as $\boldsymbol{p}-\mathbf{H}_{8} \mathbf{L}$ or $\boldsymbol{m}-\mathbf{H}_{\mathbf{8}} \mathbf{L}$, respectively). The use of these two functionalized ligands, otherwise chemically and structurally quite similar, represents a good example of how small stereochemical changes in the organic linker may dramatically affect structural features and dimensionality of the resulting solids and, hence, their final properties. With $p-\mathrm{H}_{8} \mathrm{~L}$, the solids present low dimensionality (1D) within a wide range of experimental conditions. In contrast, solids containing the linker $m-H_{8} \mathrm{~L}$ tend to acquire a $3 \mathrm{D}$ pillared open-framework for a wide range of metal ion sizes. In addition to synthetic aspects, structural details, and thermal behavior, we also demonstrate the multifunctional nature of these compounds by studying how the ligand characteristics affect relevant chemical properties in the solid state, such as proton conductivity, luminescence, and anticorrosive activity. Part of this work was presented in a congress. ${ }^{12}$

\section{EXPERIMENTAL SECTION}

Reagents and General Methods. All starting compounds were from commercial sources and used as received. In-house, deionized (DI) water was used for all syntheses and procedures.
Elemental analyses (CHN) were measured on a Perkin-Elmer 240 analyzer. Thermal analysis (TG-DTA) data were recorded on an SDTQ600 analyzer from TA Instruments. The temperature was varied from RT to $773 \mathrm{~K}$ at a heating rate of $10 \mathrm{~K} \cdot \mathrm{min}^{-1}$. Measurements were carried out on a sample in an open platinum crucible under a flow of air. Infrared spectra were obtained with an attenuated total reflectence (ATR) accessory (MIRacle ATR, PIKE Technologies, USA) coupled to a Fourier transform infrared (FTIR) spectrometer (FT/IR-4100, JASCO, Spain). All spectra were recorded in the $4000-600 \mathrm{~cm}^{-1}$ range at $4 \mathrm{~cm}^{-1}$ resolution, and 50 scans were accumulated.

Synthesis. The ligands 1,4-bis(aminomethyl)benzene- $N, N^{\prime}-b i s(-$ methanephosphonic acid) $\left(\boldsymbol{p}-\mathrm{H}_{8} \mathrm{~L}\right)$ and 1,3-bis (aminomethyl)benzene$N, N^{\prime}$-bis (methanephosphonic acid) $\left(\boldsymbol{m}-\mathbf{H}_{8} \mathbf{L}\right)$ were synthesized according to literature procedures. ${ }^{13}$

Preparation of $M-\left(p-H_{6} L\right)[M=M g$, Co, and $Z n]$. A quantity of the ligand $p-\mathrm{H}_{8} \mathrm{~L}(0.307 \mathrm{~g}, 0.600 \mathrm{mmol})$ is suspended in $10 \mathrm{~mL}$ deionized water (the ligand is not soluble in pure water). The ligand can be solubilized by addition of $\mathrm{NaOH}$ stock solution until the $\mathrm{pH}$ reaches 6.0. Then the $\mathrm{pH}$ of the resulting clear solution is reduced by addition of $\mathrm{HCl}$ stock solution until $\mathrm{pH}$ is 2 . A quantity of $\mathrm{ZnCl}_{2}$ $(0.082 \mathrm{~g}, 0.600 \mathrm{mmol})$ is separately dissolved in $5 \mathrm{~mL}$ of DI water. The $\mathrm{ZnCl}_{2}$ solution is added dropwise to the $\boldsymbol{p}-\mathrm{H}_{8} \mathrm{~L}$ ligand solution under stirring. The $\mathrm{pH}$ is finally adjusted to 2.5 , and the solution is left undisturbed at ambient conditions. After a couple days, a microcrystalline powder appears which is isolated by filtration, washed with DI water, and air-dried. Typical yields exceed $60 \%$. The same procedure was followed for the $\mathrm{Mg}^{2+}$ and $\mathrm{Co}^{2+}$ analogs, by using suitable water-soluble metal salts.

Hydrothermal syntheses were also carried out following the same procedure previously described, but the reactant solutions were treated at $413 \mathrm{~K}$ for 3 days under autogenous pressure.

As demonstrated by crystallographic studies and elemental analyses, the three analogs reported here have the general formula $\mathrm{M}$ $\left[\left(\mathrm{HO}_{3} \mathrm{PCH}_{2}\right)_{2} \mathrm{~N}(\mathrm{H}) \mathrm{CH}_{2} \mathrm{C}_{6} \mathrm{H}_{4} \mathrm{CH}_{2} \mathrm{~N}(\mathrm{H})\left(\mathrm{CH}_{2} \mathrm{PO}_{3} \mathrm{H}\right)_{2}\left(\mathrm{H}_{2} \mathrm{O}\right)_{2}\right] \cdot 2 \mathrm{H}_{2} \mathrm{O}$ $(\mathrm{M}=\mathrm{Zn}, \mathrm{Co}, \mathrm{Mg})$. $\mathbf{Z n}-\left(\boldsymbol{p}-\mathrm{H}_{6} \mathbf{L}\right)$ : anal calcd (\%) for $\mathrm{ZnC}_{12} \mathrm{H}_{30} \mathrm{O}_{16} \mathrm{~N}_{2} \mathrm{P}_{4}: 22.25 \%$ C, $4.67 \% \mathrm{H}, 4.33 \%$ N. Found: $22.30 \%$ $\mathrm{C}, 4.05 \% \mathrm{H}, 4.67 \% \mathrm{~N}$. $\mathrm{Mg}-\left(p-\mathrm{H}_{6} \mathrm{~L}\right)$ : anal calcd (\%) for $\mathrm{MgC}_{12} \mathrm{H}_{30} \mathrm{O}_{16} \mathrm{~N}_{2} \mathrm{P}_{4}$ : $23.84 \%$ C, $4.67 \% \mathrm{H}, 4.77 \%$ N. Found: $24.20 \%$ $\mathrm{C}, 4.75 \% \mathrm{H}, 4.80 \% \mathrm{~N}$. $\mathbf{C o}-\left(p-\mathrm{H}_{6} \mathrm{~L}\right)$ : anal calcd (\%) for $\mathrm{CoC}_{12} \mathrm{H}_{30} \mathrm{O}_{16} \mathrm{~N}_{2} \mathrm{P}_{4}: 22.47 \%$ C, $4.72 \% \mathrm{H}, 4.37 \%$ N. Found: $23.33 \%$ C, $4.49 \% \mathrm{H}, 4.70 \% \mathrm{~N}$.

Preparation of $M-\left(m-H_{6} L\right)[M=M g, C a, C o$, and $Z n]$. Syntheses at room temperature were carried out by slow evaporation as previously described for $\mathbf{M}-\left(p-\mathrm{H}_{6} \mathrm{~L}\right)$ compounds. The ligand $m-\mathrm{H}_{8} \mathrm{~L}$ $(0.228-0.376 \mathrm{mmol})$ was suspended in $10 \mathrm{~mL}$ deionized water and solubilized at $\mathrm{pH} 2$ in two steps, by consecutive addition of $\mathrm{NaOH}$ (up to clear solution) and $\mathrm{HCl}$ stock solutions (1-5 M). A $5 \mathrm{~mL}$ portion of a solution of the suitable metal salt $\left[\mathrm{Zn}\left(\mathrm{NO}_{3}\right)_{2} \cdot 6 \mathrm{H}_{2} \mathrm{O}, \mathrm{Mg}\right.$ $\left(\mathrm{NO}_{3}\right)_{2} \cdot 6 \mathrm{H}_{2} \mathrm{O}, \mathrm{CoCl}_{2} \cdot 6 \mathrm{H}_{2} \mathrm{O}$, or $\left.\mathrm{Ca}\left(\mathrm{NO}_{3}\right)_{2} \cdot 3 \mathrm{H}_{2} \mathrm{O}\right]$ corresponding to a molar ratio $\mathrm{M}$ :ligand $=1: 1$ was then dropwise added to the ligand solution, under stirring. For all experiments, the final $\mathrm{pH}$ was adjusted to 2.0 and the solutions were left undisturbed at ambient conditions. After several days, the microcrystalline solids were isolated as mentioned above. Typical yields exceed 60\% (except for the $\mathrm{Mg}$ derivative, obtained in $40 \%$ yield).

Syntheses under hydrothermal conditions were also screened by high-throughput methodology with a system previously reported. ${ }^{14}$ The aluminum autoclave block contains six Teflon-lined reaction chambers of $5 \mathrm{~mL}$ volume. The reaction mixture was prepared by mixing a $0.3-0.5 \mathrm{M}$ aqueous solution of suitable metal salt $\left[\mathrm{Mg}\left(\mathrm{CH}_{3} \mathrm{COOH}\right)_{2} \cdot 4 \mathrm{H}_{2} \mathrm{O}, \mathrm{Ca}\left(\mathrm{NO}_{3}\right)_{2} \cdot 3 \mathrm{H}_{2} \mathrm{O}\right.$, or $\left.\mathrm{ZnSO}_{4} \cdot \mathrm{H}_{2} \mathrm{O}\right]$ with a 0.06 or $0.07 \mathrm{M}$ aqueous solution of $\boldsymbol{m}-\mathrm{H}_{8} \mathrm{~L}$ ligand. The $\boldsymbol{m}-\mathrm{H}_{8} \mathrm{~L}$ acid was dissolved by adding dropwise an aqueous solution of $\left(\mathrm{CH}_{3}\right)_{4} \mathrm{NOH}$ to the suspension of the ligand in $25 \mathrm{~mL}$ of DI water until a homogeneous, clear solution formed. Hydrothermal reactions of $m$ $\mathrm{H}_{8} \mathrm{~L}$ acid with $\mathrm{Mg}^{2+}$ and $\mathrm{Ca}^{2+}$ were carried out at 453 and $413 \mathrm{~K}$, for two molar ratios $\mathrm{M}: m-\mathrm{H}_{8} \mathrm{~L}(1: 1$ and $4: 1)$ and several initial $\mathrm{pH}$ values, range between 1.6 and 4.0. For the $\mathrm{Zn}$ derivatives, only hydrothermal syntheses at $413 \mathrm{~K}$ were tested. The initial $\mathrm{pH}$ values were modified from 1 to 2.5 for $\mathrm{Zn}^{2+}: m-\mathrm{H}_{8} \mathrm{~L}=1: 1$ and from 2 to 9 for $\mathrm{Zn}^{2+}: m-\mathrm{H}_{8} \mathrm{~L}=$ 
Table 1. Crystallographic Data and Structure Refinements for Compounds $\mathrm{M}\left[\left(\mathrm{HO}_{3} \mathrm{PCH}_{2}\right)_{2} \mathrm{~N}(\mathrm{H}) \mathrm{CH}_{2} \mathrm{C}_{6} \mathrm{H}_{4} \mathrm{CH}_{2} \mathrm{~N}(\mathrm{H})\left(\mathrm{CH}_{2} \mathrm{PO}_{3} \mathrm{H}\right)_{2}\left(\mathrm{H}_{2} \mathrm{O}\right)_{2}\right] \cdot 2 \mathrm{H}_{2} \mathrm{O}(\mathrm{M}=\mathrm{Mg}, \mathrm{Co}, \mathrm{Zn}), \mathrm{M}-\left(p-\mathrm{H}_{6} \mathrm{~L}\right)$

\begin{tabular}{|c|c|c|c|}
\hline reference & $\mathrm{Zn}-\left(p-\mathrm{H}_{6} \mathrm{~L}\right)$ & $\mathrm{Mg}-\left(p-\mathrm{H}_{6} \mathrm{~L}\right)$ & $\mathrm{Co}-\left(p-\mathrm{H}_{6} \mathrm{~L}\right)$ \\
\hline chemical formula & $\mathrm{ZnC}_{12} \mathrm{H}_{30} \mathrm{O}_{16} \mathrm{~N}_{2} \mathrm{P}_{4}$ & $\mathrm{MgC}_{12} \mathrm{H}_{30} \mathrm{O}_{16} \mathrm{~N}_{2} \mathrm{P}_{4}$ & $\mathrm{CoC}_{12} \mathrm{H}_{30} \mathrm{O}_{16} \mathrm{~N}_{2} \mathrm{P}_{4}$ \\
\hline formula mass & 647.65 & 606.57 & 641.20 \\
\hline crystal system & triclinic & triclinic & triclinic \\
\hline space group & $P \overline{1}$ & $P \overline{1}$ & $P \overline{1}$ \\
\hline$\lambda / \AA$ & 0.2998 & 1.5406 & 1.5406 \\
\hline$a / \AA ̊$ & $6.9591(5)$ & $6.9549(15)$ & $6.9303(12)$ \\
\hline$b / \AA$ & $7.5805(4)$ & $7.5700(10)$ & $7.5793(8)$ \\
\hline$c / \AA$ & $10.6229(7)$ & $10.6511(14)$ & $10.6441(15)$ \\
\hline$\alpha / \operatorname{deg}$ & $86.816(7)$ & $87.071(16)$ & $86.949(11)$ \\
\hline$\beta / \mathrm{deg}$ & $81.464(6)$ & $81.018(10)$ & $81.250(13)$ \\
\hline$\gamma / \operatorname{deg}$ & $73.592(5)$ & $73.831(11)$ & $73.514(7)$ \\
\hline unit cell volume $/ \AA^{3}$ & $531.57(8)$ & $531.97(19)$ & $529.85(18)$ \\
\hline Z & 1 & 1 & 1 \\
\hline$V_{\text {non-H-atom }}{ }^{a} / \AA^{3}$ & 15.19 & 15.19 & 15.14 \\
\hline temperature $/ \mathrm{K}$ & 293 & 293 & 293 \\
\hline no. independent reflections & 305 & 455 & 236 \\
\hline data/restrains/parameters & $5372 / 49 / 87$ & $3928 / 46 / 81$ & $3049 / 50 / 110$ \\
\hline$R_{\mathrm{WP}}$ & 0.0923 & 0.1505 & 0.0555 \\
\hline$R_{\mathrm{P}}$ & 0.0678 & 0.1052 & 0.0407 \\
\hline$R_{\mathrm{F}}$ & 0.0417 & 0.0517 & 0.0291 \\
\hline CCDC number & 925414 & 925415 & 925416 \\
\hline
\end{tabular}

Table 2. Crystal Data and Structure Refinements for Compounds $\mathrm{M}\left[\left(\mathrm{HO}_{3} \mathrm{PCH}_{2}\right)_{2} \mathrm{~N}(\mathrm{H}) \mathrm{CH}_{2} \mathrm{C}_{6} \mathrm{H}_{4} \mathrm{CH}_{2} \mathrm{~N}(\mathrm{H})\left(\mathrm{CH}_{2} \mathrm{PO}_{3} \mathrm{H}\right)_{2}\right] \cdot n \mathrm{H}_{2} \mathrm{O}(n=1-1.5$ and $\mathrm{M}=\mathrm{Mg}, \mathrm{Ca}, \mathrm{Co}, \mathrm{Zn}), \mathrm{M}-\left(m-\mathrm{H}_{6} \mathrm{~L}\right)$

\begin{tabular}{|c|c|c|c|c|}
\hline reference & $\mathrm{Ca}-\left(m-\mathrm{H}_{6} \mathrm{~L}\right)$ & $\mathrm{Mg}-\left(m-\mathrm{H}_{6} \mathrm{~L}\right)$ & $\mathrm{Co}-\left(m-\mathrm{H}_{6} \mathrm{~L}\right)$ & $\mathrm{Zn}-\left(m-\mathrm{H}_{6} \mathrm{~L}\right)$ \\
\hline chemical formula & $\mathrm{CaC}_{12} \mathrm{H}_{24} \mathrm{O}_{13} \mathrm{~N}_{2} \mathrm{P}_{4}$ & $\mathrm{MgC}_{12} \mathrm{H}_{25} \mathrm{O}_{13.5} \mathrm{~N}_{2} \mathrm{P}_{4}$ & $\mathrm{CoC}_{12} \mathrm{H}_{24} \mathrm{O}_{13} \mathrm{~N}_{2} \mathrm{P}_{4}$ & $\mathrm{ZnC}_{12} \mathrm{H}_{24} \mathrm{O}_{13} \mathrm{~N}_{2} \mathrm{P}_{4}$ \\
\hline formula mass & 568.30 & 561.53 & 587.15 & 593.61 \\
\hline crystal system & orthorhombic & orthorhombic & orthorhombic & orthorhombic \\
\hline space group & Pmnb & Pmnb & $P 2_{1} \mathrm{nb}$ & Pmnb \\
\hline$\lambda / \AA$ & 0.2998 & 0.2998 & 1.5406 & 1.5406 \\
\hline$a / \AA$ & $22.2105(11)$ & $22.2825(7)$ & $22.3007(4)$ & $22.3117(15)$ \\
\hline$b / \AA$ & $10.8441(4)$ & $10.0310(4)$ & $10.0163(4)$ & $10.0175(5)$ \\
\hline$c / \AA$ & $8.6118(3)$ & $8.5569(3)$ & $8.6098(3)$ & $8.6021(4)$ \\
\hline$\alpha, \beta, \gamma / \operatorname{deg}$ & 90.0 & 90.0 & 90.0 & 90.0 \\
\hline unit cell volume $/ \AA^{3}$ & $2074.18(18)$ & $1912.61(16)$ & $1923.17(9)$ & $1922.64(22)$ \\
\hline$Z$ & 4 & 4 & 4 & 4 \\
\hline$V_{\text {non-H-atom }}{ }^{a} / \AA^{3}$ & 16.21 & 14.71 & 15.03 & 15.02 \\
\hline temperature/K & 293 & 293 & 293 & 293 \\
\hline no. independent reflections & 431 & 399 & 601 & 294 \\
\hline data/restrains/parameters & $3803 / 37 / 68$ & $5136 / 37 / 64$ & $4430 / 79 / 128$ & $3334 / 37 / 68$ \\
\hline$R_{\mathrm{WP}}$ & 0.0743 & 0.0771 & 0.0172 & 0.0889 \\
\hline$R_{\mathrm{P}}$ & 0.0580 & 0.0599 & 0.0116 & 0.0700 \\
\hline$R_{\mathrm{F}}$ & 0.0424 & 0.0347 & 0.0570 & 0.0305 \\
\hline CCDC number & 930353 & 930354 & 933128 & 930355 \\
\hline
\end{tabular}

4:1 by adding $\left(\mathrm{CH}_{3}\right)_{4} \mathrm{NOH}$ or $\mathrm{HNO}_{3}$ aqueous solutions. A total filling volume of $\sim 2 \mathrm{~mL}$ per reactor was used. The Co derivative was obtained by the same procedure as described above for the synthesis at room temperature but conducting the reaction hydrothermally at 413 $\mathrm{K}$ for 3 days. The reaction products were filtered off, washed with water, and dried at $323 \mathrm{~K}$. Typical yields were about $55-60 \%$.

Crystallographic studies and elemental analyses are in agreement with the formula $\mathrm{M}\left[\left(\mathrm{HO}_{3} \mathrm{PCH}_{2}\right)_{2} \mathrm{~N}(\mathrm{H}) \mathrm{CH}_{2} \mathrm{C}_{6} \mathrm{H}_{4} \mathrm{CH}_{2} \mathrm{~N}(\mathrm{H})\right.$ $\left.\left(\mathrm{CH}_{2} \mathrm{PO}_{3} \mathrm{H}\right)_{2}\right] \cdot n \mathrm{H}_{2} \mathrm{O}(\mathrm{M}=\mathrm{Ca}, \mathrm{Mg}, \mathrm{Zn}, \mathrm{Co} ; n=1-1.5)$ for the reported compounds. $\mathbf{C a}-\left(\boldsymbol{m}-\mathbf{H}_{\mathbf{6}} \mathbf{L}\right)$ : anal calcd (\%) for Ca$\mathrm{C}_{12} \mathrm{H}_{24} \mathrm{O}_{13} \mathrm{~N}_{2} \mathrm{P}_{4}: 25.36 \% \mathrm{C}, 4.27 \% \mathrm{H}, 4.93 \% \mathrm{~N}$. Found: $26.36 \% \mathrm{C}$, $4.46 \% \mathrm{H}, 5.01 \%$ N. $\mathrm{Mg}-\left(m-\mathrm{H}_{6} \mathrm{~L}\right)$ : anal calcd (\%) for
$\mathrm{MgC}_{12} \mathrm{H}_{25} \mathrm{O}_{13,5} \mathrm{~N}_{2} \mathrm{P}_{4}: 25.67 \%$ C, $4.49 \% \mathrm{H}, 4.99 \% \mathrm{~N}$. Found: $25.26 \%$ $\mathrm{C}, 4.12 \% \mathrm{H}, 4.93 \% \mathrm{~N} . \mathbf{Z n}-\left(\boldsymbol{m}-\mathrm{H}_{6} \mathrm{~L}\right)$ : anal calcd (\%) for $\mathrm{ZnC}_{12} \mathrm{H}_{24} \mathrm{O}_{13} \mathrm{~N}_{2} \mathrm{P}_{4}: 24.28 \%$ C, $4.07 \% \mathrm{H}, 4.72 \%$ N. Found: $23.96 \%$ C, $3.43 \% \mathrm{H}, 4.68 \% \mathrm{~N}$. $\mathrm{Co}-\left(\boldsymbol{p}-\mathrm{H}_{6} \mathrm{~L}\right)$ : anal calcd (\%) for $\mathrm{CoC}_{12} \mathrm{H}_{24} \mathrm{O}_{13} \mathrm{~N}_{2} \mathrm{P}_{4}: 24.55 \%$ C, $4.12 \% \mathrm{H}, 4.77 \%$ N. Found: $24.37 \%$ C, $4.59 \% \mathrm{H}, 4.71 \% \mathrm{~N}$.

Crystallography Study. Laboratory X-ray powder diffraction (XRPD) patterns were collected on a PANanalytical X'Pert Pro diffractometer in a Bragg-Brentano reflection configuration by using a $\mathrm{Ge}(111)$ primary monochromator $(\mathrm{Cu} \mathrm{K} \alpha 1)$ and the X'Celerator detector. XRPD patterns were autoindexed using the DICVOL06 program $^{15}$ in triclinic unit cells, for $\mathbf{M}-\left(p-\mathbf{H}_{6} \mathbf{L}\right)$, and in an 
orthorhombic cell, for $\mathbf{M}-\left(m-\mathrm{H}_{6} \mathrm{~L}\right)$. For the structural determination of $\mathrm{Zn}-\left(p-\mathrm{H}_{6} \mathrm{~L}\right), \mathrm{Mg}-\left(m-\mathrm{H}_{6} \mathrm{~L}\right)$, and $\mathrm{Ca}-\left(m-\mathrm{H}_{6} \mathrm{~L}\right)$, powder X-ray diffraction data were collected at the high resolution beamline ID31 of the ESRF, European Synchrotron Radiation Facility (Grenoble, France). A wavelength of $0.2998 \AA$ was selected with a double-crystal Si (111) monochromator and calibrated with Si NIST ( $a=5.43094$ $\AA$ ). The Debye-Scherrer configuration was used with the sample loaded in a rotating borosilicate glass capillary of diameter of $1.0 \mathrm{~mm}$. The overall measuring time was $\approx 100 \mathrm{~min}$ to have very good statistics over the angular range $1.0-15^{\circ}$ (in $2 \theta$ ). The data from the multianalyzer $\mathrm{Si}(111)$ stage were normalized and summed into $0.003^{\circ}$ step size with local software. Their crystal structures were solved following an ab initio methodology. The structure determinations were carried out by direct methods using the program Expo2009 ${ }^{16}$ for $\mathrm{Zn}-\left(p-\mathrm{H}_{6} \mathbf{L}\right)$ and $\mathrm{Ca}-\left(m-\mathrm{H}_{6} \mathbf{L}\right)$. Partial structural models were obtained and the missing atoms were localized by difference of Fourier maps. The structures were optimized by the Rietveld method ${ }^{17}$ using the program GSAS ${ }^{18}$ and the graphic interface EXPGUI. ${ }^{19}$ The following soft constraints were imposed in order to preserve chemically reasonable geometries for the phosphonate, amine groups, methylene groups, and aromatic ring: $/ \mathrm{PO}_{3} \mathrm{C}$ tetrahedron $/ \mathrm{P}-\mathrm{O}(1.53(1) \AA ̊), \mathrm{P}-\mathrm{C}(1.80(1) \AA ̊), \mathrm{O} \cdots \mathrm{O}$ $(2.55(2) \AA), \quad \mathrm{O} \cdots \mathrm{C}(2.73(2) \AA), / \mathrm{N}\left(\mathrm{CH}_{2}\right)_{3}$ amine group $/ \mathrm{N}-\mathrm{C}$ $(1.50(1) \AA), C \cdots C(2.45(2) \AA)$ and/aryl/aromatic ring/C-C (1.40(1) $\AA ̊), C_{\text {ring }} \cdots C_{\text {ring }}(2.40(1) \AA), C_{\text {ring }} \cdots C_{\text {ring }}(2.78(1) \AA)$. Hydrogen atoms were not included in the refinements. The final weight factors for the soft constrains were fixed between 30 and 20. Only one of the isotropic atomic displacement parameters was refined. The crystal structures of the remaining solids were obtained by Rietveld refinement using as a starting model the crystal structure of $\mathbf{Z n}-(p$ $\left.\mathbf{H}_{6} \mathrm{~L}\right)$ and $\mathbf{C a}-\left(m-\mathrm{H}_{6} \mathrm{~L}\right)$. Crystal structures have been deposited at CCDC, and the reference codes are also given in Table 1 , for $\mathbf{M}-(\boldsymbol{p}$ $\left.\mathbf{H}_{6} L\right)$ and in Table 2 for $\mathbf{M}-\left(m-\mathbf{H}_{6} L\right)$.

On the other hand, thermodiffractometric studies for the Co derivatives of both organic ligands, as representative compounds of each family, were carried out for the sample loaded in an Anton Paar HTK $1200 \mathrm{~N}$ chamber under static air. Data were collected at 303, 323, $348,373,398,423,448,473,498,523,548 \mathrm{~K}$ for both compounds. All measures were done with a heating rate of $10 \mathrm{~K} \cdot \mathrm{min}^{-1}$ and a delay time of $5 \mathrm{~min}$ to ensure thermal stabilization. Data acquisitions were carried out between $4^{\circ}$ and $50^{\circ}(2 \theta)$ due to the low crystallinity of the sample. A step size of $0.017^{\circ}$ and an equivalent counting time of $230 \mathrm{~s} \mathrm{step}^{-1}$ were used.

Proton Conductivity Study. Impedance data were collected on cylindrical pellets $(\sim 10 \mathrm{~mm}$ of diameter and $\sim 1 \mathrm{~mm}$ of thickness) obtained by pressing $\sim 0.15 \mathrm{~g}$ of sample at $500 \mathrm{MPa}$ for 2 min between porous $\mathrm{C}$ electrodes (Sigracet, GDL $10 \mathrm{BB}$, no $\mathrm{Pt}$ ). Impedance data were collected using a HP4284A impedance analyzer over the frequency range from $20 \mathrm{~Hz}$ to $1 \mathrm{MHz}$ with an applied voltage of 1 V. All measurements were electronically controlled by the winDETA package of programs. ${ }^{20}$

Electrical measurements were taken in a double-wall temperaturecontrolled glass chamber with a gas inlet and outlet. The temperature of the glass chamber was controlled by a Julabo F32-MA refrigerated/ heating circulator from 283 to $297 \mathrm{~K}$ every $2 \mathrm{~K}$ with a heating rate of $0.4 \mathrm{~K} \cdot \mathrm{min}^{-1}$ using EasyTEMP software. Samples were equilibrated for $40 \mathrm{~min}$ after each step in temperature, measured in closest vicinity to the sample. The relative humidity $(\mathrm{RH})$ was obtained by a continuous flow of water-saturated nitrogen at different temperatures through the cell. The pellet was equilibrated at a given $\mathrm{RH}$ for $18 \mathrm{~h}$ to ensure a fixed water content of the sample. $\mathrm{RH}$ is approximately constant in the narrow measured temperature range of $14 \mathrm{~K}$.

Photoluminescence. The luminescent properties of the $p-\mathbf{H}_{8} \mathbf{L}$ ligand and the $\mathrm{M}(\mathrm{II})$ derivatives were recorded at room temperature as solids using a Cary Eclipse Fluorimeter, employing a solid state attachment to mount the samples. Excitation and emission spectra were recorded over appropriate wavelength ranges, using a scan rate of $100 \mathrm{~nm} / \mathrm{min}$.

Corrosion Inhibition Study. A modified protocol is used based on NACE Standard TM0169-95 (Item No. 21200), National
Association of Corrosion Engineers, Houston TX, U.S.A. ${ }^{21}$ Corrosion specimens (pretreated carbon steel, grade C1010) are prepared according to the well-established protocol above. Each specimen is immersed in a control solution (no inhibitor) or in a test solution (containing either ligand $p-\mathrm{H}_{8} \mathrm{~L}(1.0 \mathrm{mM})$ or a combination of a $\mathrm{M}^{2+}$ salt and $p-\mathrm{H}_{8} \mathrm{~L}$ (both at $(1.0 \mathrm{mM})$ ) and corrosion progress is monitored by visual inspection for 7 days. Then, the specimens are removed from solution, surface samples are taken for spectroscopic studies, and corrosion products are cleaned by the standard NACE method above to determine corrosion rates from mass loss.

\section{RESULTS AND DISCUSSION}

Syntheses. The presence of highly basic $\mathrm{N}$ atoms on the skeleton of both ligands, $p-H_{8} \mathrm{~L}$ and $m-\mathrm{H}_{8} \mathrm{~L}$, cause their intramolecular protonation. This is also demonstrated by the crystal structure of the "free" ligand, which shows that two phosphonic acid groups (one from each side of the aromatic ring) are monodeprotonated (and possess the form $-\mathrm{PO}_{3} \mathrm{H}^{-}$), whereas the remaining two are fully protonated (and possess the form $-\mathrm{PO}_{3} \mathrm{H}_{2}$ ) (results not shown). The $\mathrm{N}$ atoms are both likely protonated $\left(\mathrm{NH}^{+}\right)$as was determined by single crystal $\mathrm{X}$ ray diffraction for analog compounds. ${ }^{22}$ Protonation constants are not known for either ligands, but based on similar tetraphosphonates $^{6 \mathrm{f}}$ at $\mathrm{pH} \sim 2.5-3.0$, both $\mathrm{H}_{8} \mathrm{~L}$ ligands should possess a " $2-$ " overall charge with two phosphonic acid groups being fully protonated and the other two being singly deprotonated. Hence, the ligands $p-\mathbf{H}_{8} \mathbf{L}$ and $m-\mathbf{H}_{8} \mathbf{L}$ are zwitterions in their free (uncomplexed) forms; see the upper part of Scheme 1.

Scheme 1. Interaction of $p-\mathrm{H}_{8} \mathrm{~L}$ with Divalent Metal Cations to Produce the 1D Hybrids

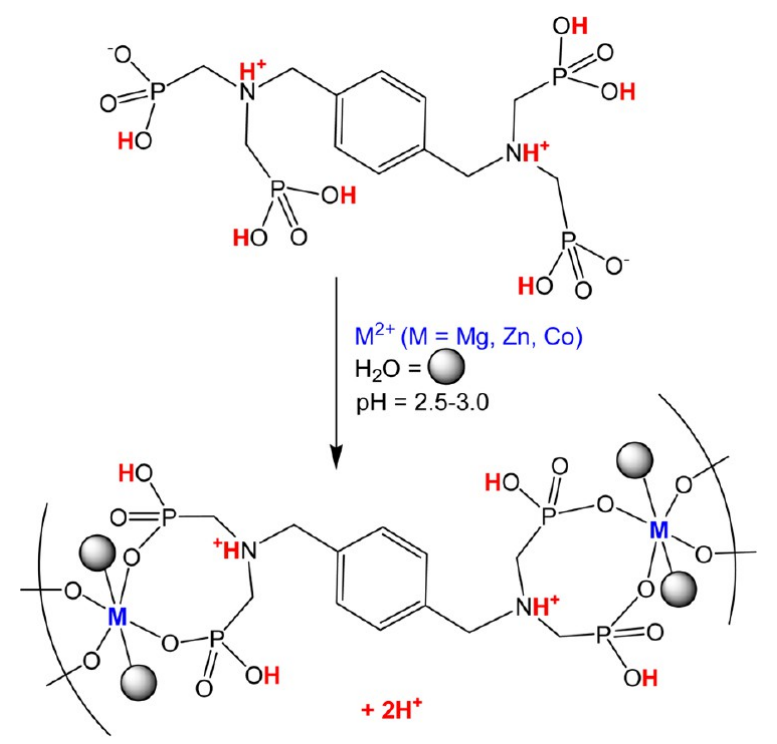

Upon interaction of $p-\mathbf{H}_{8} \mathrm{~L}$ with metal ions, two further deprotonations occur on the fully protonated phosphonic acid groups. This is a well-known phenomenon for acidic ligands. Hence, the $\mathbf{H}_{8} \mathbf{L}$ ligands now possess a total "2-" charge, with each phosphonic acid group being monodeprotonated, while the $\mathrm{N}$ atoms are protonated, still exhibiting a zwitterionic character. ${ }^{23}$ It is expected that frameworks with divalent metal ions (synthesized at sufficiently low $\mathrm{pH}$ regions) will be neutral, due to precise charge neutralization. A generalized reaction can be envisioned (proton content on the $\boldsymbol{p}-\mathbf{H}_{\mathbf{8}} \mathrm{L}$ ligand, as example, is also shown color-coded), Scheme 1. 


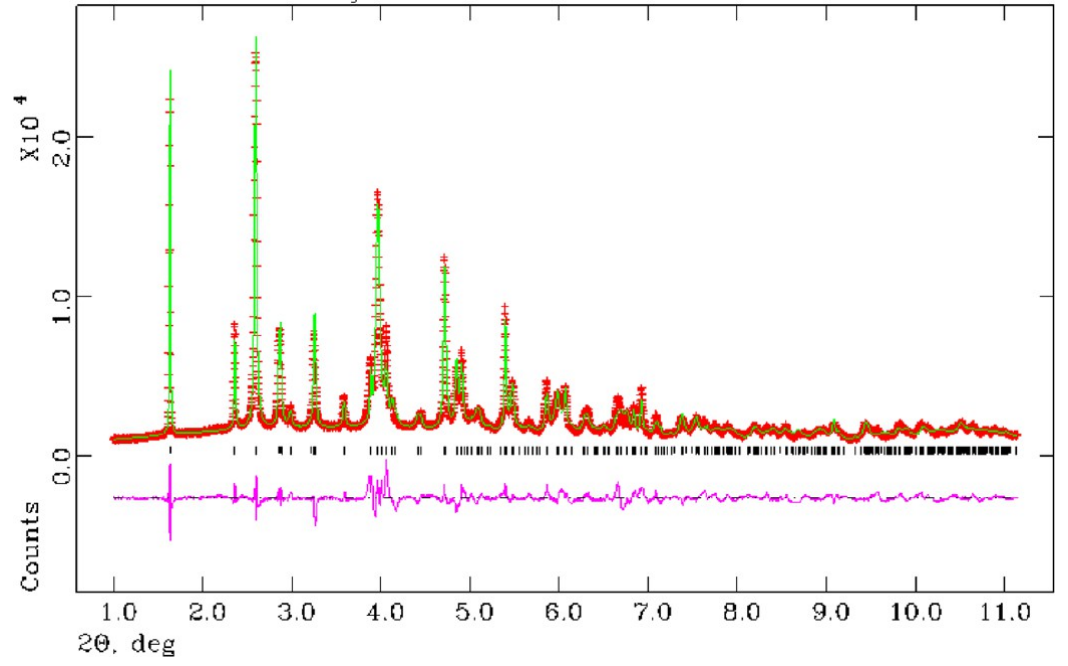

Figure 1. Final observed (crosses), calculated (solid line), and difference plots for the Rietveld refinement of synchrotron XRPD data for Zn-( $p$ $\mathbf{H}_{\mathbf{6}} \mathbf{L}$ ). The vertical bars highlight the positions of the allowed diffraction peaks.
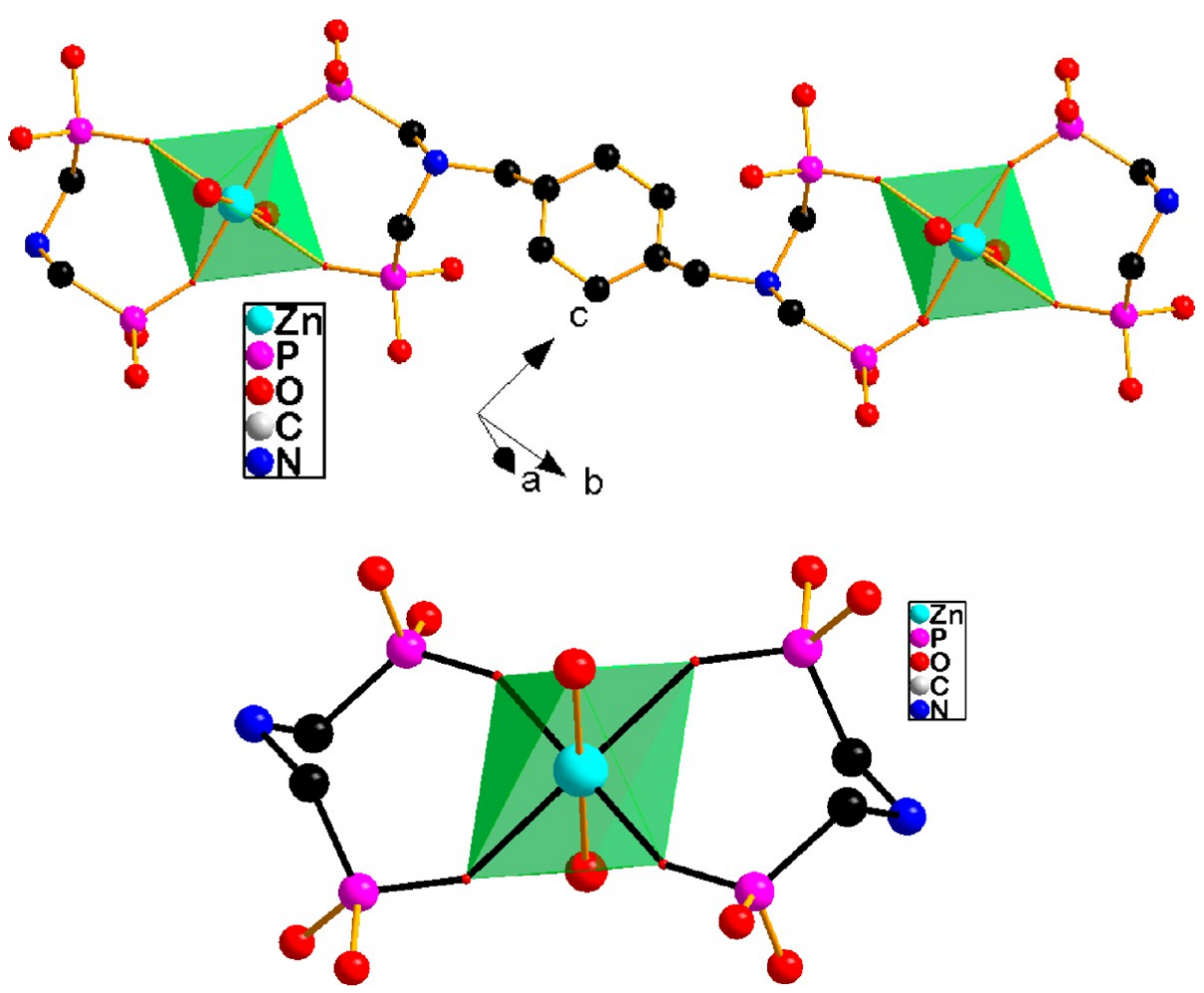

Figure 2. (upper) Basic structural "dimeric" unit for $\mathbf{Z n}-\left(p-\mathbf{H}_{6} \mathbf{L}\right)$ (the structure is the same for the $\mathrm{Mg}$ and Co derivatives). (lower) $\mathrm{Zn}$ coordination environment. Bonds in the 8-membered rings are highlighted in black. The waters of crystallization are omitted for clarity.

Under this principle of electroneutrality, $\mathbf{M}-\left(p-\mathbf{H}_{6} \mathbf{L}\right)(\mathrm{M}=$ $\mathrm{Mg}, \mathrm{Zn}$, and $\mathrm{Co})$ and $\mathbf{M}-\left(\boldsymbol{m}-\mathbf{H}_{\mathbf{6}} \mathbf{L}\right)(\mathrm{M}=\mathrm{Ca}, \mathrm{Mg}$, and $\mathrm{Co})$ were isolated as microcrystalline solids by slow crystallization at room temperature, as for other divalent metal tetraphosphonates. ${ }^{4 \mathrm{~h}, 6 \mathrm{f}}$ However, no crystalline material could be prepared by the reaction of $m-\mathrm{H}_{8} \mathrm{~L}$ with the $\mathrm{Zn}^{2+}$ solution at $\mathrm{pH} 2$. Lower $\mathrm{pH}$ values led to the precipitation of the ligand alone.

The high effectiveness observed for the reaction between $p$ $\mathbf{H}_{8} \mathbf{L}$ ligand with divalent metal salts at room temperature seems in contrast to the results obtained under hydrothermal conditions. Thus, only $\mathbf{C o}-\left(p-\mathbf{H}_{6} \mathbf{L}\right)$ was obtained hydrothermally as a highly crystalline solid, as confirmed by its X-ray powder diffraction pattern (see the SI, Figure S1). An amorphous solid was isolated for $\mathrm{Zn}$ and no product was isolated for $\mathrm{Mg}$ under similar synthetic conditions.

The high-throughput screening of the system $\mathrm{Zn}^{2+} / \boldsymbol{m}-\mathrm{H}_{8} \mathbf{L}$ did not reveal any solid at 453 or $413 \mathrm{~K}$ by hydrothermal reaction for $1: 1$ and $4: 1 \mathrm{Zn}: m-\mathrm{H}_{8} \mathrm{~L}$ molar ratios in the studied $\mathrm{pH}$ range, 2.0-9.0. A single crystalline solid, $\mathbf{Z n}-\left(m-\mathrm{H}_{8} \mathrm{~L}\right)$, was isolated at $413 \mathrm{~K}$ for a molar ratio $1: 1$ and $\mathrm{pH}=1$. Similar results were obtained for the calcium derivative. Thus, amorphous solids were obtained at $413 \mathrm{~K}<T<453 \mathrm{~K}$, for both 1:1 and 4:1 metal/ligand molar ratios, in the whole $\mathrm{pH}$ range. $\mathrm{Ca}-\left(m-\mathrm{H}_{8} \mathrm{~L}\right)$ could be obtained as crystalline material using a Ca: $m-\mathrm{H}_{8} \mathrm{~L}$ molar ratio $1: 1$, at $\mathrm{pH} \sim 1.6$, and $T \leq 413 \mathrm{~K}$. $\mathrm{Mg}-\left(\mathrm{m}-\mathrm{H}_{8} \mathrm{~L}\right)$, could be prepared with high crystallinity at 


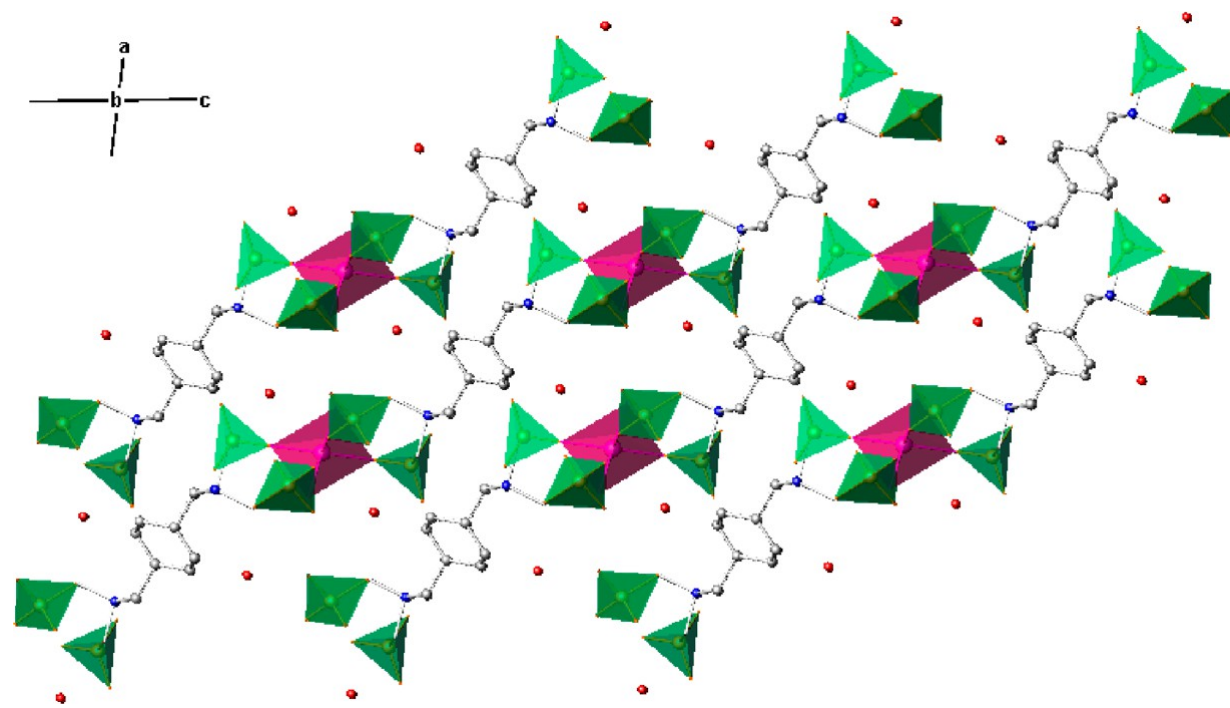

Figure 3. Packing of the hybrid chains in the crystal structure of $\mathrm{M}\left[\left(\mathrm{HO}_{3} \mathrm{PCH}_{2}\right)_{2} \mathrm{~N}(\mathrm{H}) \mathrm{CH}_{2} \mathrm{C}_{6} \mathrm{H}_{4} \mathrm{CH}_{2} \mathrm{~N}(\mathrm{H})\left(\mathrm{CH}_{2} \mathrm{PO}_{3} \mathrm{H}\right)_{2}\left(\mathrm{H}_{2} \mathrm{O}\right)_{2}\right] \cdot 2 \mathrm{H}_{2} \mathrm{O}(\mathrm{M}=\mathrm{Mg}$, $\mathrm{Co}, \mathrm{Zn}$ ). Color codes: $\mathrm{O}_{3} \mathrm{PC}$ tetrahedra, green; $\mathrm{MO}_{6}$ octahedra, purple.

variable molar ratio $(1: 1$ or $4: 1)$, temperature ( 453 or $413 \mathrm{~K})$, and $\mathrm{pH}$ 2.0-3.4. Higher $\mathrm{pH}$ values gave amorphous solids. With this ligand, the compounds obtained hydrothermally exhibit higher crystallinity than those prepared by crystallization at room temperature (Supporting Information Figure S2). In general, yields between 50 and $60 \%$ were obtained.

Crystal Structures. $\mathrm{M}\left[\left(\mathrm{HO}_{3} \mathrm{PCH}_{2}\right)_{2} \mathrm{~N}(\mathrm{H}) \mathrm{CH}_{2} \mathrm{C}_{6} \mathrm{H}_{4} \mathrm{CH}_{2} \mathrm{~N}(\mathrm{H})-\right.$ $\left.\left(\mathrm{CH}_{2} \mathrm{PO}_{3} \mathrm{H}\right)_{2}\left(\mathrm{H}_{2} \mathrm{O}\right)_{2}\right] \cdot 2 \mathrm{H}_{2} \mathrm{O}$. All $\mathbf{M}-\left(p-\mathrm{H}_{6} \mathrm{~L}\right)(\mathrm{M}=\mathrm{Mg}, \mathrm{Co}, \mathrm{Zn})$ compounds crystallize in the triclinic system and are isostructural. The crystal structure of the $\mathrm{Zn}$ derivative was solved $\mathrm{ab}$ initio from synchrotron powder diffraction data and was used as a starting model for the Rietveld refinement of the remaining two compounds. The final Rietveld plot for $\mathbf{Z n}-(p$ $\left.\mathbf{H}_{6} \mathbf{L}\right)$ is given in the Figure 1 and those corresponding to $\mathrm{Mg}$ and Co derivatives are given as Supporting Information (Figures S3 and S4, respectively). Relevant crystallographic data are presented in Table 1.

The asymmetric part of the unit cell contains one $\mathrm{M}^{2+}$ ion, located in a special position, half a unit of the $p-\mathbf{H}_{6} \mathbf{L}^{2-}$ ligand, possessing an inversion center in the aromatic ring, and two crystallographically independent water molecules. The ligand molecule is assumed to adopt a zwitterionic form as indicated below. ${ }^{23}$ Although hydrogens could not be located in the present crystallographic analyses, several superimposed bands of medium intensity, appearing at $2600-2200 \mathrm{~cm}^{-1}$ in the FTIR spectra, might be attributed to $\mathrm{R}_{3} \mathrm{~N}-\mathrm{H}^{+}$vibration modes. ${ }^{24}$

All three $\mathrm{Zn}-\left(p-\mathrm{H}_{6} \mathrm{~L}\right), \mathbf{M g}-\left(p-\mathrm{H}_{6} \mathrm{~L}\right)$, and $\mathrm{Co}-\left(p-\mathrm{H}_{6} \mathrm{~L}\right)$ show a monodimensional network built from organicinorganic chains linked to each other through H-bonds. The basic "dimeric" building block of the chains is given in Figure 2. The chains are composed of ligand molecules with each bisphosphonate end being linked to a $\mathrm{M}^{2+}$ ion in a bidentate fashion. $\mathrm{M}^{2+}$ distorted octahedral are formed by four equatorial oxygens from four phosphonate groups of two neighboring $\boldsymbol{p}$ $\mathbf{H}_{6} \mathbf{L}^{2-}$ molecules and two additional water molecules (Ow1) in apical positions. A second crystallographically independent water molecule Ow2 is only interacting by hydrogen bond with the phosphonate groups, connecting adjacent chains. $\mathrm{M}-\mathrm{O}$ bond distances and angles are shown in Supporting Information Table S1.
The metal polyhedra are bridged by the $p-\mathbf{H}_{6} \mathbf{L}^{2-}$ moiety which acts as a chelating ligand through the oxygens $\mathrm{O} 1$ and O4 of two crystallographically independent phosphonates forming 8-membered rings. This way of coordination results in infinite chains running parallel along the $c$-axis (Figure 3 ). Uncoordinated oxygen atoms from the phosphonate groups point outside of the chains and they are linked to each other and metal-bound water molecules by strong H-bonds. The 3D structure is stabilized by $\mathrm{O}-\mathrm{H} \cdots \mathrm{O}$ hydrogen bonding and possibly weak interactions $\mathrm{N}-\mathrm{H} \cdots \mathrm{O}$. The contribution of stabilizing $\pi-\pi$ interactions between phenyl rings may be neglected because they are too far apart from each other ${ }^{22}$ (see Supporting Information Figure S5 and Tables S2-S4).

As shown for $\mathbf{C o}-\left(p-\mathbf{H}_{6} \mathrm{~L}\right)$, this structure is preserved even when the synthesis is carried out under hydrothermal conditions at $413 \mathrm{~K}$. In contrast to this finding, $\mathbf{C a}-\left(p-\mathrm{H}_{6} \mathrm{~L}\right)$, obtained hydrothermally at $423 \mathrm{~K}$, exhibits a 3D pillared framework, with xylenediamine groups connecting layers composed of alternating $\mathrm{CaO}_{6^{-}}$and $\mathrm{PO}_{3} \mathrm{C}$-polyhedra. ${ }^{22}$ The structural variability, observed in these two compounds, associated to changes in connectivity to the metal ion, may be attributed either to a variation in preference of coordination according to the metal ionic radii and/or slight changes in the hydrothermal synthesis of the products, with higher temperatures $(T \geq 423 \mathrm{~K})$ of reaction favoring higher connectivities. The importance of reaction temperature in determining the metal/tetraphosphonate ligand connectivity is also supported by the fact that the compound $\mathrm{Mn}\left[\left(\mathrm{HO}_{3} \mathrm{PCH}_{2}\right)_{2} \mathrm{~N}(\mathrm{H})\right.$ $\left.\left(\mathrm{CH}_{2}\right)_{4}(\mathrm{H}) \mathrm{N}\left(\mathrm{CH}_{2} \mathrm{PO}_{3}\right)_{2}\right]$ hydrothermally synthesized at 423 $\mathrm{K}$ also exhibits a $3 \mathrm{D}$ pillared framework. ${ }^{23 \mathrm{~b}}$ By slightly lowering the reaction temperature at $413 \mathrm{~K}$, as is the case here, the ligand seems to coordinate only to the metal ions possessing ionic radii in the vicinity of $0.7 \AA\left(\mathrm{Mg}^{2+} 0.72 \AA, \mathrm{Zn}^{2+} 0.74 \AA\right.$, and $\mathrm{Co}_{\mathrm{LS}}{ }^{2+} 0.65 \AA$ or $\mathrm{Co}_{\mathrm{HS}}{ }^{2+} 0.74 \AA$ ) in a single bidentate fashion. This coordination mode leaves room for two water molecules to enter the metal coordination sphere in a trans configuration, thus resulting in a $1 \mathrm{D}$ solid.

There are only a few examples of monodimensional polymeric divalent metal tetraphosphonates. One family of 1D solids, $\mathrm{M}^{\mathrm{II}}-\mathrm{HDTMP},\left[\left(\mathrm{M}=\mathrm{Sr}^{2+}, \mathrm{Ba}^{2+25 \mathrm{a}, \mathrm{b}} \mathrm{Cu}^{2+} ;\right.\right.$; $5 \mathrm{a}$ HDTMP = hexamethylenediamine-tetrakis(methylenephos- 

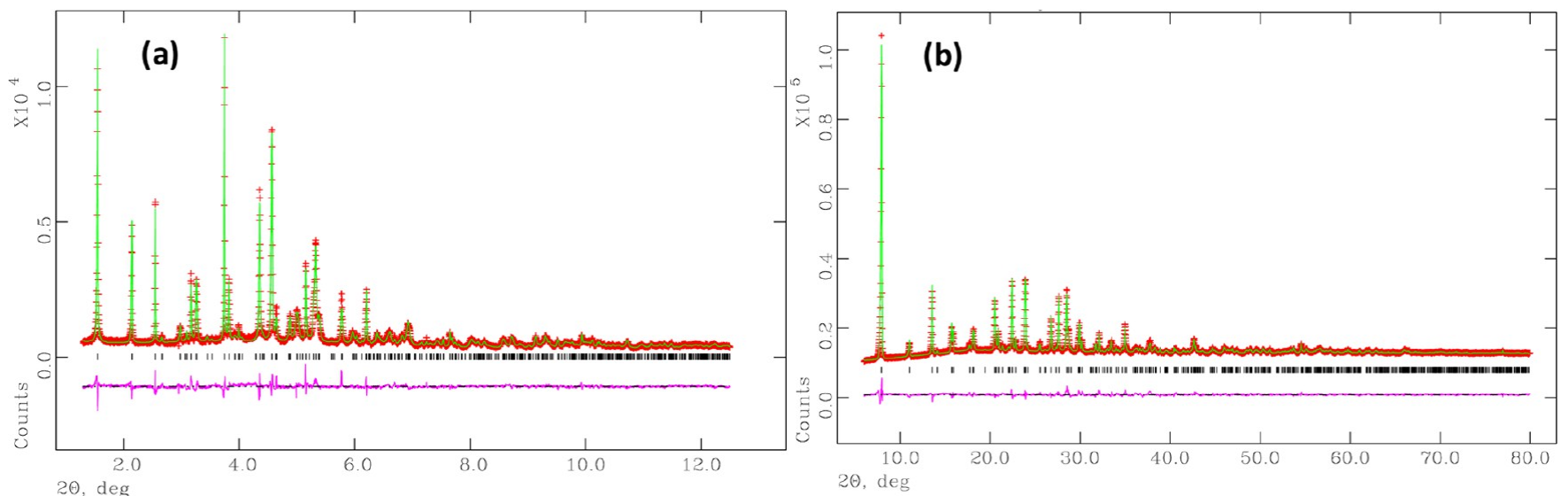

Figure 4. Final observed (crosses), calculated (solid line), and difference plots for the Rietveld refinements of (a) $\mathbf{C a}-\left(\boldsymbol{m}\right.$ - $\left.\mathrm{H}_{6} \mathrm{~L}\right)$, synchrotron XRPD data at $0.2998 \AA$ and (b) $\mathrm{Co}-\left(m-\mathrm{H}_{6} \mathrm{~L}\right)$, laboratory XRPD. The vertical bars highlight the positions of the allowed diffraction peaks.
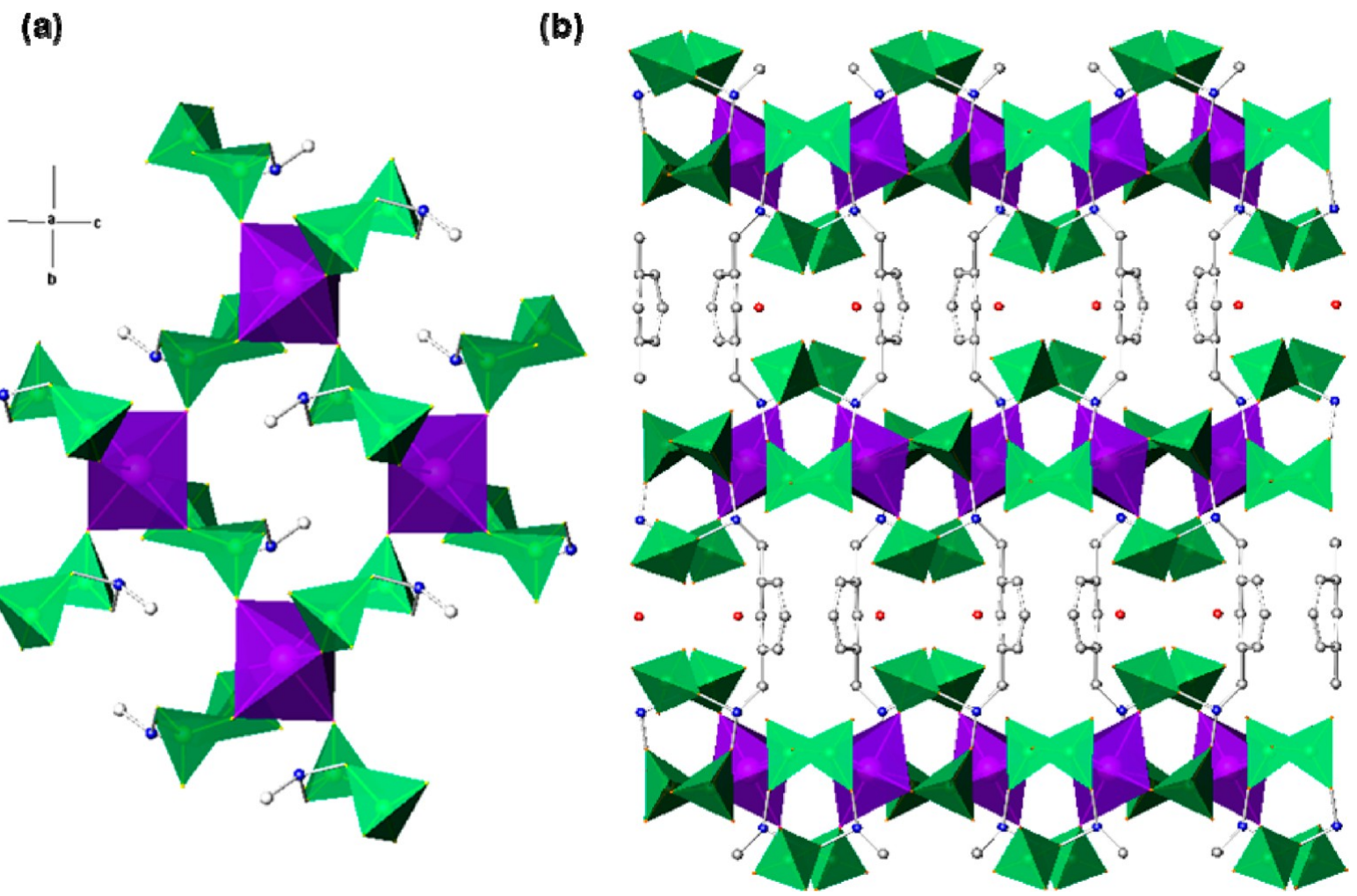

Figure 5. (a) Detail of the connectivity in the inorganic layer for $\mathbf{M}-\left(\boldsymbol{m}-\mathrm{H}_{6} \mathbf{L}\right)(\mathrm{M}=\mathrm{Ca}, \mathrm{Mg}, \mathrm{Co}$, and $\mathrm{Zn})$. (b) 3D open-framework, viewed along the [010].

phonic acid), $\left.\left(\mathrm{H}_{2} \mathrm{O}_{3} \mathrm{PCH}_{2}\right)_{2} \mathrm{~N}\left(\mathrm{CH}_{2}\right)_{6} \mathrm{~N}\left(\mathrm{CH}_{2} \mathrm{PO}_{3} \mathrm{H}_{2}\right)_{2}\right]$, show a one-dimensional hybrid chain structure, where only one phosphonate group of each aminomethylenephosphonic motif is coordinated to the metal center by one oxygen atom. The other uncoordinated phosphonate group interacts with neighboring $-\mathrm{PO}_{3} \mathrm{H}^{-}$moieties and $\mathrm{H}_{2} \mathrm{O}$ molecules by hydrogen bonds. The other series, $\mathrm{M}^{\mathrm{II}}-\mathrm{EDTMP}^{27}(\mathrm{M}=\mathrm{Ca}$, $\mathrm{Sr}$ ) are monodimensional solids with the tetraphosphonate EDTMP (ethylenediamine-tetrakis (methylenephosphonic acid), $\left.\left(\mathrm{H}_{2} \mathrm{O}_{3} \mathrm{PCH}_{2}\right)_{2} \mathrm{~N}\left(\mathrm{CH}_{2}\right)_{2} \mathrm{~N}\left(\mathrm{CH}_{2} \mathrm{PO}_{3} \mathrm{H}_{2}\right)_{2}\right)$, again formed by the double chelating-bridging function of the tetraphosphonate ligand.

$\mathrm{M}\left[\left(\mathrm{HO}_{3} \mathrm{PCH}_{2}\right)_{2} \mathrm{~N}(\mathrm{H}) \mathrm{CH}_{2} \mathrm{C}_{6} \mathrm{H}_{4} \mathrm{CH}_{2} \mathrm{~N}(\mathrm{H})\left(\mathrm{CH}_{2} \mathrm{PO}_{3} \mathrm{H}\right)_{2}\right] \cdot n \mathrm{H}_{2} \mathrm{O}$ (n $=1-1.5) \cdot \mathbf{M}-\left(m-\mathrm{H}_{6} \mathrm{~L}\right)(\mathrm{M}=\mathrm{Ca}, \mathrm{Mg}, \mathrm{Co}, \mathrm{Zn})$ can be obtained as polycrystalline solids by crystallization at room temperature or hydrothermally. Their X-ray patterns were indexed in similar orthorhombic unit cells. The extinction conditions were consistent with the space groups $P m n b$ or $P 2_{1} n b$. So, initially, the centrosymmetric space group $P m n b$ was selected for ab initio structural solution by direct methods using the synchrotron powder diffraction data collected for $\mathbf{C a}-(m-$ $\left.\mathbf{H}_{6} \mathbf{L}\right)$. Its crystal structure could be fully completed and refined in the centrosymmetric space group and the final structure was used as a starting model for the Rietveld refinements of the remaining compounds. These refinements converged for the remaining solids except for cobalt derivative. A difference Fourier map for this solid revealed a slight different orientation of the aromatic ring, with the carbon atoms C5 and C7 of the aromatic ring out of the special position $(0.75, y, z)$ that they are occupying in the centrosymmetric group. Therefore, the 
noncentrosymmetric space group $P 2_{1} n b$ was adopted for the final Rietveld refinement for $\mathrm{Co}-\left(\boldsymbol{m}-\mathrm{H}_{6} \mathrm{~L}\right)$. Figure 4 shows the final Rietveld plots for $\mathbf{C a}-\left(m-\mathrm{H}_{6} \mathrm{~L}\right)$ and $\mathrm{Co}-\left(m-\mathrm{H}_{6} \mathrm{~L}\right)$. Those other Rietveld plots corresponding to the $\mathrm{Mg}$ and $\mathrm{Zn}$ derivatives are given as Supporting Information (Figures S6 and S7, respectively). Relevant crystallographic data for $\mathbf{M}-(\mathbf{m}$ $\left.\mathbf{H}_{6} \mathbf{L}\right)(\mathrm{M}=\mathrm{Ca}, \mathrm{Mg}, \mathrm{Co}, \mathrm{Zn})$ are presented in Table 2.

All $\mathbf{M}-\left(\boldsymbol{m}-\mathbf{H}_{\mathbf{6}} \mathrm{L}\right)$ show a $3 \mathrm{D}$ pillared open-framework where the inorganic layer exhibits the same mixed bidentate/ monodentate metal/ligand connectivity as already described for $\mathrm{Ca}-\left(p-\mathrm{H}_{6} \mathrm{~L}\right){ }^{22}$ The asymmetric part of the unit cell contains one $\mathrm{M}^{2+}$ ion, located in a special position, a half unit of the $\boldsymbol{m}-\mathbf{H}_{6} \mathbf{L}^{2-}$ ligand, for $\mathbf{M}-\left(\boldsymbol{m}-\mathrm{H}_{6} \mathbf{L}\right)$ solids $(\mathrm{M}=\mathrm{Ca}, \mathrm{Mg}, \mathrm{Zn})$, and one crystallographically independent lattice water in special position. For $\mathrm{Co}-\left(m-\mathrm{H}_{6} \mathrm{~L}\right)$, the asymmetric part contains a full unit of the $m-\mathrm{H}_{6} \mathrm{~L}^{2-}$ ligand, besides the metal atom and the lattice water. Compound $\mathrm{Mg}-\left(\boldsymbol{m}-\mathrm{H}_{6} \mathrm{~L}\right)$ crystallizes with an additional half water molecule per formula, but it could not be found by Fourier differences. In general, the inorganic layers are built from $\mathrm{M}^{2+}$ distorted octahedra (see Supporting Information Table S5 and S6). As for $\mathbf{M}-\left(\boldsymbol{p}-\mathrm{H}_{6} \mathbf{L}\right)$ compounds, four equatorial oxygens come from four phosphonate groups of two $\boldsymbol{m}-\mathrm{H}_{6} \mathrm{~L}^{2-}$ molecules; however the oxygen atoms in axial position are occupied by two other phosphonate groups instead of water molecules. So, in this case, the tetraphosphonate units act as chelating as well as a monodentate ligands forming 8-membered ring nets composed of alternating $\mathrm{MO}_{6}$ octahedra and $\mathrm{PO}_{3} \mathrm{C}$-polyhedra (Figure 5a). ${ }^{22}$ In this case, neighboring layers, are connected along the $a$-axis by the xylenediamine groups. However, the presence of the diaminetretraphosphonates groups in meta-position relative to the aromatic ring favors the presence of $1 \mathrm{D}$ channels running parallel to the $b$-axis within the interlayer region (Figure $5 \mathrm{~b}$ ). Tilting and alternating arrangement of the aromatic rings impedes, however, the existence of such channels in the framework of $\mathbf{C a}-\left(p-\mathbf{H}_{6} \mathrm{~L}\right)$. The lattice water is situated close to the center of the channels interacting by $\mathrm{H}$-bond with an oxygen atom of the phosphonate group that acts as monodentate ligand $(\mathrm{O} \cdots \mathrm{O}$ interacting distance between 2.63 and $2.90 \AA$ ). The second non-coordinating oxygen of this phosphonate group also points inward the channels, and it is strongly interacting by H-bond $(\sim 2.45 \AA)$ with an equivalent oxygen atom of the phosphonate group of the adjacent layer.

It should be noted that this framework is adopted by a number of divalent ions, within a wide range of sizes, and even though the reactions were conducted at room temperature. This coordination mode is not only interesting by the high dimensionality (3D) of the resulting solids, but also because the absence of water directly coordinated to the metal centers, which in turn may reinforce properties such as luminescence. The absence of metal bound water is also a noticeable characteristic in other tetraphosphonate ligand-based 3D pillared frameworks ${ }^{6 e, f}$ presenting a remarkable high proton conductivity. The latter compounds, however, show distinctive metal/ligand coordination, with metal center being now connected to six oxygens of six different phosphonate groups.

The connectivity showed by the $p-\mathbf{H}_{6} \mathbf{L}^{2-}$ and $m-\mathbf{H}_{6} \mathbf{L}^{2-}$ ligands with many divalent metal ions contrasts with that corresponding to $\mathrm{Cu}^{2+}$ derivatives. For both derivatives, the tetraphosphonate moiety acts as endo-tridentate ligand, ${ }^{26}$ where the $\mathrm{N}$ atom also participates in chelating the metal centers. Besides, the different conformation induced by the xylene groups with the substituent in para or meta determine the network of the resulting compounds. Thus, although both compounds show 2D frameworks, $\mathrm{Cu}-\left(p-\mathrm{H}_{6} \mathrm{~L}\right)$ is built by anionic organic-inorganic layers which charge is compensated by additional $\mathrm{Cu}\left(\mathrm{H}_{2} \mathrm{O}\right)_{6}{ }^{2+}$ ions. However, $\mathbf{C u}-\left(\boldsymbol{m}-\mathrm{H}_{6} \mathbf{L}\right)$ shows neutral organic-inorganic layers where the presence of the $m$ xylene groups induces the formation of hydrophilic hemicavities, occupied by water molecules, between adjacent layers. $^{26}$

Thermal Behavior and IR Spectroscopy. Thermal stabilities of $\mathbf{M}-\left(p-\mathrm{H}_{6} \mathrm{~L}\right)$ and $\mathbf{M}-\left(m-\mathrm{H}_{6} \mathrm{~L}\right)$ solids were studied by TG-DTA analysis and X-ray thermodiffraction. Thermogravimetric analyses for $\mathbf{M}-\left(\boldsymbol{p}-\mathbf{H}_{6} \mathbf{L}\right)$ are displayed in Figure $6 \mathrm{a}$.
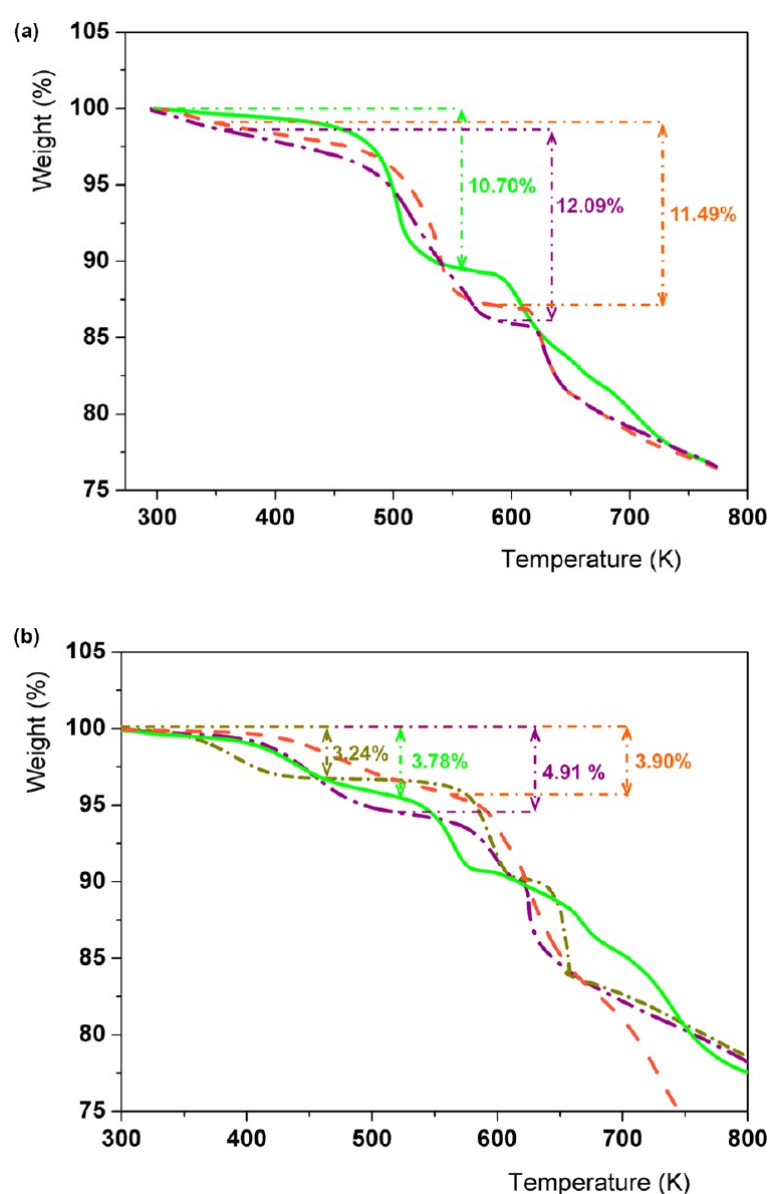

Figure 6. TGA curves for (a) $\mathbf{M}-\left(\boldsymbol{p}-\mathrm{H}_{6} \mathbf{L}\right)$ and (b) $\mathbf{M}-\left(\boldsymbol{m}-\mathrm{H}_{6} \mathrm{~L}\right)$ solids $[\mathrm{M}=\mathrm{Zn}$ (green), $\mathrm{M}=\mathrm{Co}$ (orange), $\mathrm{M}=\mathrm{Mg}$ (purple), and $\mathrm{M}=\mathrm{Ca}$, (dark green)].

$\mathrm{Zn}-\left(\boldsymbol{p}-\mathrm{H}_{6} \mathrm{~L}\right)$ is stable up to $423 \mathrm{~K}$. Water was completely removed between 423 and $553 \mathrm{~K}$ (10.7\%, calculated $11.1 \%)$, but a clear distinction between bound and lattice water molecules was not apparent, as they are removed in one step. Thermal decomposition of the hybrid compound takes place above $583 \mathrm{~K} . \mathbf{M g}-\left(p-\mathrm{H}_{6} \mathrm{~L}\right)$ and $\mathrm{Co}-\left(p-\mathrm{H}_{6} \mathrm{~L}\right)$ solids show similar thermal behavior, demonstrated by a gradual weight loss from room temperature up to $583 \mathrm{~K}$. The overall associated weight loss of $13.10 \%$ and $12.30 \%$, respectively, corresponds to a water content slightly higher than four molecules per formula ( $11.87 \%$ and $11.20 \%$, respectively), attributed to the loss of some physisorbed water at low temperature. Thermal decomposition of the phosphonate ligand starts above $600 \mathrm{~K}$. 

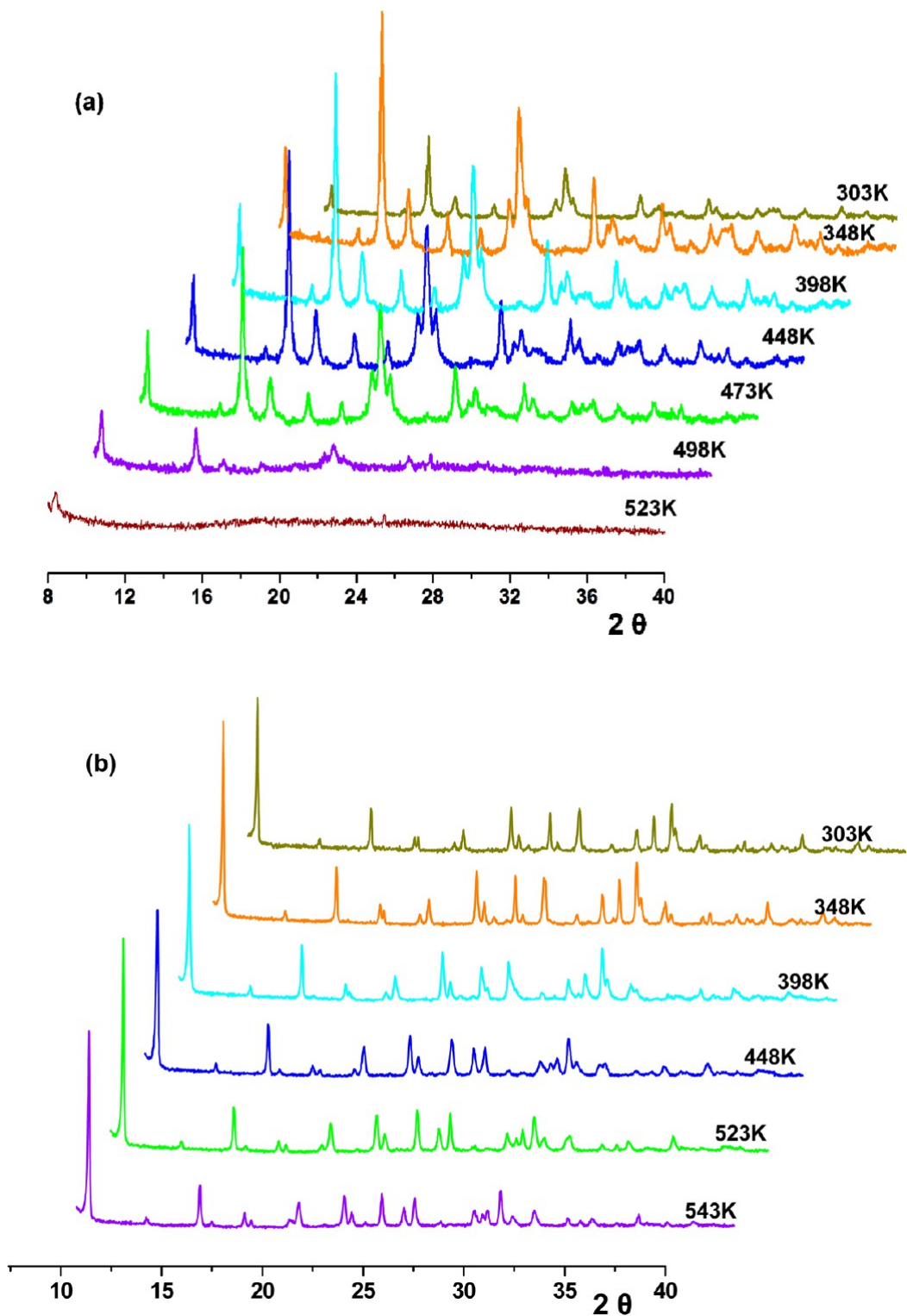

Figure 7. Thermodiffractometric studies for (a) Co- $-\left(p-\mathrm{H}_{6} \mathrm{~L}\right)$ and $(\mathrm{b}) \mathrm{Co}-\left(m-\mathrm{H}_{6} \mathrm{~L}\right)$ in the $303-543 \mathrm{~K}$ temperature range.

The TGA curves for $\mathbf{M}-\left(\boldsymbol{m}-\mathbf{H}_{\mathbf{6}} \mathbf{L}\right)$, Figure $6 \mathrm{~b}$, show two welldefined weight losses corresponding to the removal of the lattice water (endothermic peak in DTA curves) and the combustion of the organic moiety (exothermic peaks in DTA curves). For $\mathrm{Ca}-\left(m-\mathrm{H}_{6} \mathrm{~L}\right)$, the water molecule is eliminated between 340 and $423 \mathrm{~K}$. The overall associated weight loss of $3.1 \%$ is in agreement with that calculated $(3.0 \%)$ for one water molecule. The resulting anhydrous phase is stable up to $570 \mathrm{~K}$, above which the combustion of the ligand starts. $\mathrm{Zn}$ and Co derivatives behave similarly, with associated weight losses of $3.8 \%$ and $3.9 \%$ (calculated, $3.0 \%$ and $3.1 \%$ ), respectively. For both compounds, the mass loss takes place sequentially between $360-493 \mathrm{~K}\left[\mathrm{Zn}-\left(\boldsymbol{m}-\mathrm{H}_{6} \mathrm{~L}\right)\right]$ and $360-550 \mathrm{~K}[\mathrm{Co}-$ $\left.\left(\boldsymbol{m}-\mathrm{H}_{6} \mathrm{~L}\right)\right]$. A slightly higher range of temperature was observed for the dehydration of $\mathbf{M g}-\left(\boldsymbol{m}-\mathbf{H}_{6} \mathrm{~L}\right)(405-570 \mathrm{~K})$. The measured water loss, $4.9 \%$, agrees well with the $4.8 \%$ calculated for 1.5 water molecules. The anhydrous phases formed start to decompose almost immediately exhibiting different patterns, that of the cobalt derivative showing the fastest decomposition.
Thermodiffractometric analyses were carried out to precisely monitor possible structural changes upon thermal treatments for two samples as representative members of each series: Co$\left(p-\mathrm{H}_{6} \mathrm{~L}\right)$, Figure $7 \mathrm{a}$, and $\mathrm{Co}-\left(m-\mathrm{H}_{6} \mathrm{~L}\right)$, Figure $7 \mathrm{~b}$. The Rietveld refinement for $\mathrm{Co}-\left(p-\mathrm{H}_{6} \mathrm{~L}\right)$ heated in situ at $473 \mathrm{~K}$ (Rietveld fit, Supporting Information Figure S8) shows a slight increase in the unit cell volume, from $529.8(1)$ to $533.7(3) \AA^{3}$, as a consequence of a small thermal expansion of the cell. It should be noted that the disagreement factors increase more than $2 \%$ when the lattice water is not taken into account in the Rietveld refinement. This confirms that only a small fraction of water has been removed in agreement with the thermal analysis $(\sim 2.7 \%)$. Complete removal of water at higher temperature causes amorphization of the solids, although decomposition of the organic portion does not take place below $580 \mathrm{~K}$. During the thermal treatment and up to $473 \mathrm{~K}$, the crystal structure is not significantly modified. Only small structural changes are noted, the main feature being a rotation of the phosphonate group P2 causing an additional distortion and tilting of the $\mathrm{CoO}_{6}$ octahedra (Supporting Information Figure S9 and Table S7). 

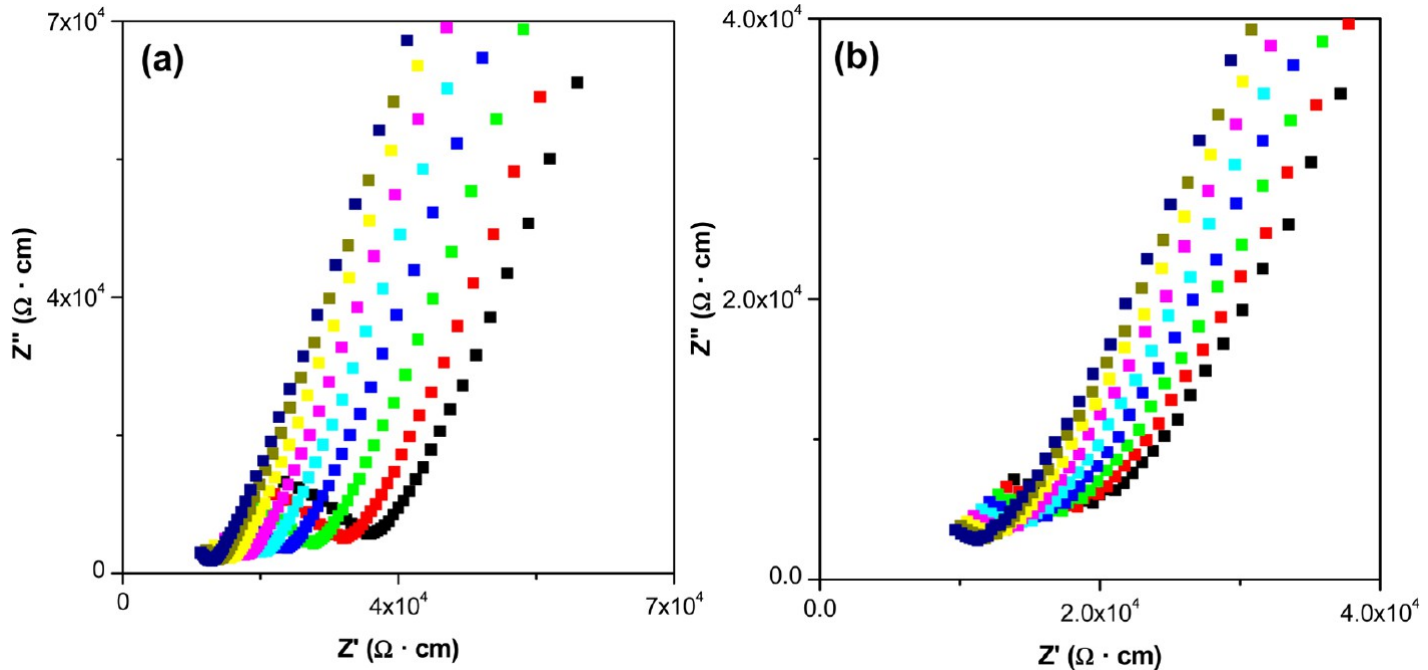

Figure 8. Plot of the complex impedance plane for (a) $\mathbf{M g}-\left(p-\mathrm{H}_{6} \mathrm{~L}\right)$ and (b) $\mathbf{Z n}-\left(m-\mathrm{H}_{6} \mathbf{L}\right)$ at $98 \% \mathrm{RH}$ and nine temperatures: 283 (black), 285 (red), 286 (green), 288 (blue), 290 (cyan), 292 (magenta), 293 (yellow), 295 (dark yellow) and $297 \mathrm{~K}$ (navy).
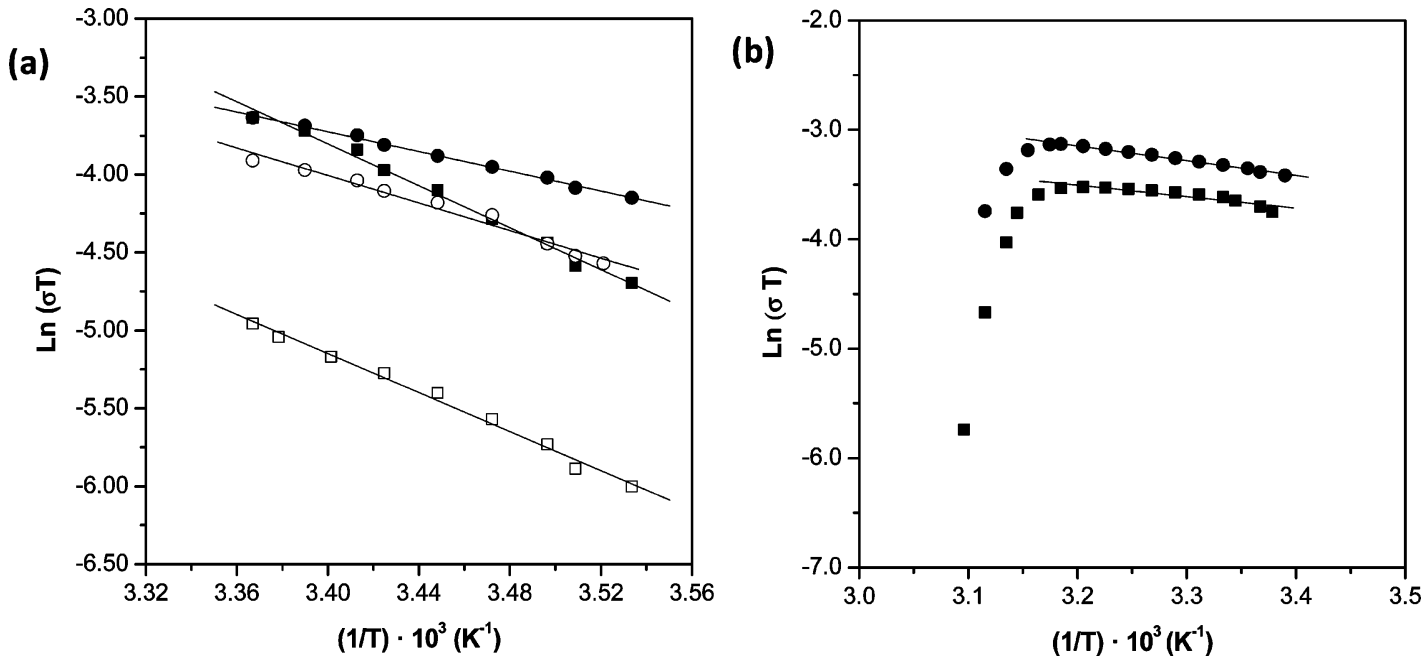

Figure 9. (a) Arrhenius plots vs $T^{-1}$ for $\mathbf{M g}-\left(p-\mathbf{H}_{6} \mathbf{L}\right)$ (square symbols) and $\mathbf{Z n}-\left(m-\mathrm{H}_{6} \mathbf{L}\right)$ (circle symbols) at two relative humidities $69 \%$ (open) and $98 \%$ (solid). (b) Arrhenius plots vs $T^{-1}$ for $\mathbf{M g}-\left(\boldsymbol{p}-\mathbf{H}_{6} \mathbf{L}\right)$ (square symbols) and $\mathbf{Z n}-\left(\boldsymbol{m}-\mathbf{H}_{6} \mathbf{L}\right)$ (circle symbols) in the temperature range 296 at $314 \mathrm{~K}$ (samples initially exposed to $98 \% \mathrm{RH})$.

Thus, the angle in the equatorial plane $\mathrm{O} 1-\mathrm{Co}-\mathrm{O} 4$ varies from $89.5(8)^{\circ}$ to $81.8(8)^{\circ}$ upon heating at $473 \mathrm{~K}$. Co- $\left(m-\mathbf{H}_{6} \mathbf{L}\right)$ maintains its crystalline integrity upon thermal dehydration (Figure 7b), with only minor changes in the unit cell parameters (small contraction of $a$ and $b$ parameters) and a slightly higher distortion of the metal coordination sphere (see Supporting Information Figure S10). The Rietveld plot corresponding to the structural refinement of the sample Co- $\left(m-\mathbf{H}_{6} \mathbf{L}\right)$ heated at $543 \mathrm{~K}$ is given in Supporting Information Figure S11. The refined unit cell parameters for this sample were $a=22.083(2) \AA, b=9.8540(8) \AA, c=$ 8.7553(9) $\AA$, and $V=1905.2(4) \AA^{3}$. Rehydration was not observed when the sample was placed under a controlled humid atmosphere of a saturated $\mathrm{NaCl}$ solution at room temperature, for several days.

The IR spectra (Supporting Information Figures S12 and S13) of both families of hybrids tetraphosphonates show similar spectroscopic features and only small differences in the widths and intensities of the bands are observed. For $\mathbf{M}-\left(p-\mathbf{H}_{6} \mathbf{L}\right)$, the different nature of the water molecules found previously by $\mathrm{X}$ - ray diffraction analysis may be also appreciated. So, two different bands in the $\mathrm{O}-\mathrm{H}$ stretching region are distinguished: (1) a small and sharp band at $\sim 3605 \mathrm{~cm}^{-1}$, corresponding to coordinated water, that is absent for $\mathbf{M}-\left(\boldsymbol{m}-\mathbf{H}_{6} \mathbf{L}\right)$ solids; and (2) a broader band centered at $3200 \mathrm{~cm}^{-1}$ typical of water molecules interacting strongly through $\mathrm{H}$-bonds. So, the absence of the band at $3600 \mathrm{~cm}^{-1}$ for $\mathrm{M}-\left(\boldsymbol{p}-\mathrm{H}_{6} \mathrm{~L}\right)$ confirms the lability of the water for these latter compounds. The bending $\mathrm{H}-\mathrm{O}-\mathrm{H}$ vibration of the water is located at 1630 $\mathrm{cm}^{-1}$, as a broad band. Two other bands observed at 2861 and $2333 \mathrm{~cm}^{-1}$ are likely due to $\nu(\mathrm{P}-\mathrm{OH})$ and the overtone $2 \delta(\mathrm{P}-$ $\mathrm{O}-\mathrm{H})$, respectively. The multiple bands associated with the phosphonate groups, in the $900-1200 \mathrm{~cm}^{-1}$ region, ${ }^{28}$ as well as the aromatic and aliphatic $\mathrm{C}-\mathrm{H}$ stretching vibrations are found in positions similar to other metal phosphonates. ${ }^{25,27,28}$

Proton Conductivity Results. Ionic conduction in solid state materials ${ }^{29}$ occurs intrinsically through the material or via some carrier mediated pathway (e.g., $\mathrm{H}_{2} \mathrm{O}, \mathrm{H}_{3} \mathrm{O}^{+}, \mathrm{OH}^{-}$, etc.). Preliminary proton conductivity studies have been conducted for samples $\mathbf{M g}-\left(p-\mathrm{H}_{6} \mathrm{~L}\right)$ and $\mathrm{Zn}-\left(m-\mathrm{H}_{6} \mathrm{~L}\right)$. Upon humid- 
ification for more than $18 \mathrm{~h}$, both samples exhibited stable conductivities values (Supporting Information Figure S14) which confirms the role of water as proton carrier and grain boundary remover. Impedance spectra for $\mathrm{Mg}-\left(p-\mathrm{H}_{6} \mathrm{~L}\right)$ and $\mathrm{Zn}-\left(\boldsymbol{m}-\mathrm{H}_{\mathbf{6}} \mathrm{L}\right)$ at two different relative humidities $(\mathrm{RH}), 69$ and $98 \%$, and a temperature range from 283 to $297 \mathrm{~K}$ are shown in the SI (Figures S15 and S16) and Figure 8, respectively.

When $\mathbf{M g}-\left(\boldsymbol{p}-\mathrm{H}_{6} \mathrm{~L}\right)$ and $\mathbf{Z n}-\left(\boldsymbol{m}-\mathbf{H}_{6} \mathrm{~L}\right)$ are exposed to the highest $\mathrm{RH}$ value of $98 \%$, spikes are observed which have associated capacitances of $\sim 1 \mu \mathrm{F}$. The spikes are inclined to the $Z$-axis by $\sim 70^{\circ}$, and this indicates a partial-blocking electrode response that allows limited diffusion; therefore, the conducting species must be ionic, i.e. $\mathrm{H}^{+}$ions. The total pellet resistances, $R_{\mathrm{T}}$, were obtained from the intercept of the spikes and/or the arcs (low frequency end) on the Z-axis. At 98\% RH and $\mathrm{T}=$ $297 \mathrm{~K}, \sigma$ are close to $9.4 \times 10^{-5} \mathrm{~S} \cdot \mathrm{cm}^{-1}$ for both compounds. This value is intermediate between those characteristic of some phosphonate-based MOF materials $\left(\sigma \sim 3.5-5 \times 10^{-5} \mathrm{~S} \cdot \mathrm{cm}^{-1}\right.$, at $298 \mathrm{~K}$ and $95-98 \% \mathrm{RH})^{29,30}$ and those reported for other metal tetraphosphonates $\left(1.6-8 \times 10^{-3} \mathrm{~S} \cdot \mathrm{cm}^{-1}\right),{ }^{6 e, f}$ as well as some MOF materials exhibiting proton conductivities near to $10^{-2} \mathrm{~S} \cdot \mathrm{cm}^{-1} \cdot{ }^{6 \mathrm{~h}, 7,8}$ As expected for water-mediated proton conductors, decreasing $\mathrm{RH}$ results in lower conductivities; see Supporting Information Figure S15 and S16.

The overall pellet conductivities for $\mathbf{M g}-\left(p-\mathrm{H}_{6} \mathrm{~L}\right)$ and $\mathrm{Zn}-$ $\left(m-H_{6} L\right)$, in traditional Arrhenius format, are given in Figure 9a for two $\mathrm{RH}$ values. The derived activation energies for $\mathbf{M g}-(p$ $\mathrm{H}_{6} \mathrm{~L}$ ) were $\sim 0.50 \mathrm{eV}$, for both $\mathrm{RH}$ values, and 0.25 and $0.35 \mathrm{eV}$ for $98 \%$ and $69 \% \mathrm{RH}$, for $\mathrm{Zn}-\left(m-\mathrm{H}_{6} \mathrm{~L}\right)$. The latter material exhibits activation energies within the range typically attributed to a Grotthuss transfer mechanism via water molecules, $0.1-0.4$ $\mathrm{eV}^{31}$

These values are consistent with those found for other 3D pillared metal phosphonates containing monodimensional channels filled with uncoordinated water which participates in $\mathrm{H}$-bond networks with the $\mathrm{POH}$ groups pointing inward the channels. ${ }^{6, f}$ However, for the monodimensional solid the activation energies are slightly high to be attributed to a Grotthuss transfer mechanism and indicate some other processes such as direct diffusion of additional protons with water molecules (vehicle mechanism). The vehicle mechanism implies the diffusion of hydrated protons or proton-containing groups, e.g. $\mathrm{H}_{3} \mathrm{O}^{+}$, as a whole in a medium of low viscosity and high diffusion. This proton-transport has been reported in many acid solid hydrates, perovskites, zeolites, etc. ${ }^{32-34}$ The 1D compound ferrous oxalate dehydrate, which possesses a remarkably high conductivity at room temperature $(1.3 \times$ $\left.10^{-3} \mathrm{~S} \cdot \mathrm{cm}^{-1}\right)$, also presents a metal coordination sphere with two axial positions being occupied by water molecules. ${ }^{6 a}$ However, differently from $\mathbf{M}-\left(p-\mathbf{H}_{6} \mathbf{L}\right)$, the arrangement of the coordinated water molecules in ferrous oxalate allows formation of strong hydrogen bonds with the framework oxalate oxygen atoms. In addition, the metal centers are well separated by a long organic linker. In this case, the more labile lattice water establishing hydrogen bond networks with the free $\mathrm{POH}$ groups seems to be responsible for the measured conductivities.

In these materials, the proton conductivity is thermally activated. Starting with samples pellets at $297 \mathrm{~K}$ and $98 \% \mathrm{RH}$ (Figure 9), the conductivity slightly increases with the temperature up to $314 \mathrm{~K}\left(1.39 \times 10^{-4}\right.$ and $9.75 \times 10^{-5}$ $\mathrm{S} \cdot \mathrm{cm}^{-1}$ for $\mathrm{Zn}-\left(m-\mathrm{H}_{6} \mathrm{~L}\right)$ and $\mathrm{Mg}-\left(p-\mathrm{H}_{6} \mathrm{~L}\right)$ respectively $)$, above which it drops dramatically. This behavior, observed for other MOF-based proton conductors, may be attributed to a diminution of the conductivity by drastically decreasing the number of proton carriers. ${ }^{\text {a }}$

Photoluminescence Results. The $\boldsymbol{p}-\mathrm{H}_{8} \mathrm{~L}$ phosphonic acid precursor and the derivatives derived from $\mathrm{Mg}$ and $\mathrm{Zn}$ exhibit a photoluminescent response (Figure 10), while the Co based
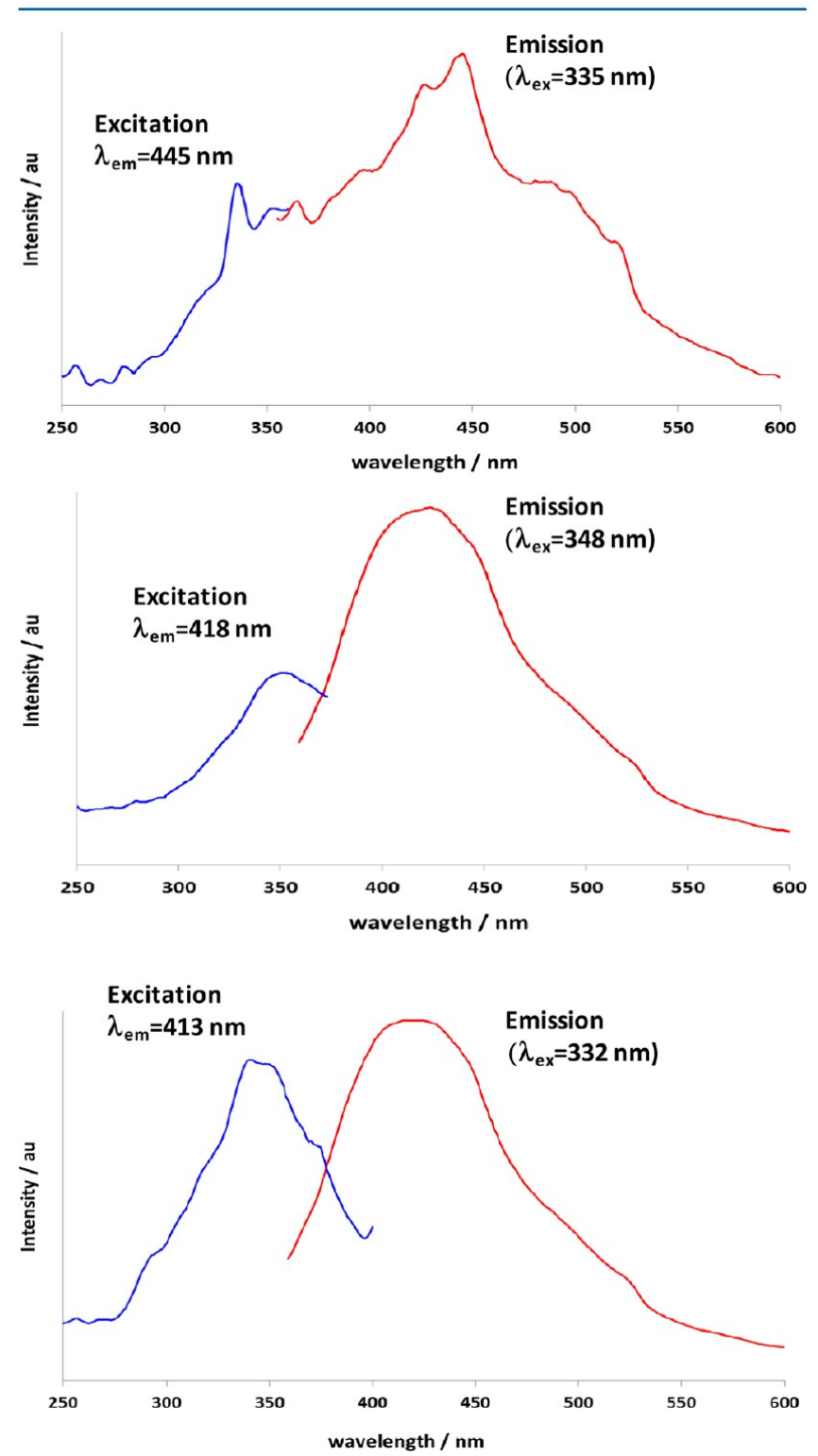

Figure 10. Solid state emission (red) and excitation (blue) spectra of $p-\mathbf{H}_{8} \mathbf{L}$ (top), $\mathbf{M g}-\left(p-\mathbf{H}_{6} \mathbf{L}\right)$ (middle), and $\mathbf{Z n}-\left(p-\mathbf{H}_{6} \mathbf{L}\right)$ (bottom).

derivative shows no response to UV-vis radiation over the measurable range. All three of the samples that display photoluminescence are excited over the range 332-348 nm, which implies that it is the substituted phenyl ring of the phosphonate anion which is being excited, it is most likely that this arises from a $\pi-\pi^{*}$ transition. The emissions of all three are observed with the two metal derivatives are in the range of 413-445 nm with the observed emissions for $\mathbf{M g}-\left(p-\mathrm{H}_{6} \mathrm{~L}\right)$ and $\mathrm{Zn}-\left(p-\mathrm{H}_{6} \mathrm{~L}\right)$ being seen at 418 and $413 \mathrm{~nm}$, respectively. The two metal based materials also have similar full width at half-maximum (fwhm) values of $105 \mathrm{~nm}$ for the $\mathrm{Mg}$ derivative and $109 \mathrm{~nm}$ for the $\mathrm{Zn}$ derivative.

It has been shown elsewhere that ligand to metal charge transfer (LMCT) followed by relaxation of the metal to the 
ground state will result in emission at different wavelengths. ${ }^{35}$ This is not observed for these materials and the similarity of the spectra of the ligand and the metal derived materials therefore suggests that the observed luminescence is entirely ligand based, with the slight change in $\lambda_{\max }$ in the emission spectra being accounted for by formation of the anionic species, which will perturb the electronic structure of the phosphonate to a small extent.

Corrosion Inhibition. Corrosion experiments were designed to explore the ability of ligand $p-H_{8} \mathrm{~L}$ to act synergistically with metal ions and create a protective film acting as a corrosion barrier on carbon steel surfaces. Two $\mathrm{pH}$ regions were included, 2.5 and 5.0, and the overall results are shown in Figure 11.

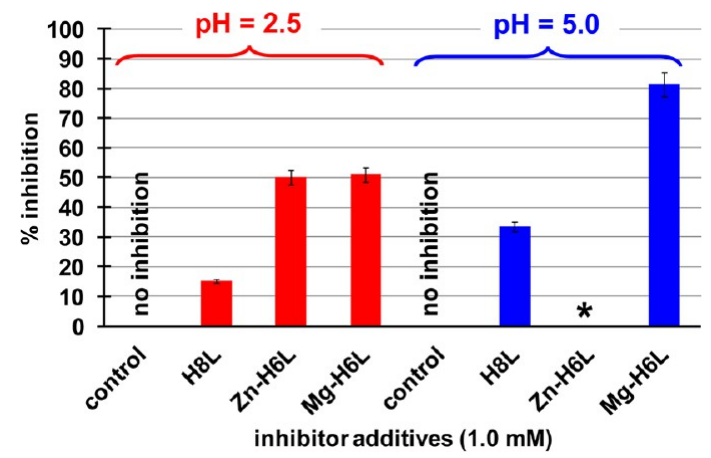

Figure 11. Corrosion inhibition efficiency (\%) of the free ligand $p$ $\mathbf{H}_{8} \mathbf{L}$ and the hybrids $\mathbf{Z n}-\left(p-\mathrm{H}_{6} \mathrm{~L}\right)$ and $\mathbf{M g}-\left(p-\mathrm{H}_{6} \mathrm{~L}\right)$, compared to the "control" ( $0 \%$ inhibition) at $\mathrm{pH} 2.5$ (red bars) and 5.0 (blue bars). The * indicates that no measurements were made for the $\mathbf{Z n}-\left(p-\mathrm{H}_{6} \mathrm{~L}\right)$ hybrid due to bulk precipitation.

The $\boldsymbol{p}-\mathbf{H}_{8} \mathbf{L}$ ligand alone (in the absence of metal ions) offers marginal corrosion protection, with only $\sim 15 \%$ efficiency. However, a synergistic combination of $\mathrm{Zn}^{2+}$ and $p-\mathrm{H}_{8} \mathrm{~L}$ in a $1: 1$ molar ratio (under identical conditions used to prepare crystalline $\left.\mathbf{Z n}-\left(p-\mathrm{H}_{6} \mathrm{~L}\right) \mathrm{pH}=2.5\right)$ seems to offer increased corrosion protection for carbon steel based on visual observations (Figure 12). According to mass loss measurements, the corrosion rate for the control is $0.138 \mathrm{~mm} /$ year whereas that for $\mathbf{Z n}-\left(\boldsymbol{p}-\mathbf{H}_{\mathbf{6}} \mathbf{L}\right)$ is $0.069 \mathrm{~mm} /$ year $(\sim 50 \%$ inhibition).

A synergistic combination of $\mathrm{Mg}^{2+}$ and $\boldsymbol{p}-\mathrm{H}_{8} \mathrm{~L}$ in a 1:1 molar ratio (under identical conditions used to prepare crystalline $\left.\mathbf{M g}-\left(p-\mathbf{H}_{6} \mathbf{L}\right), \mathrm{pH}=2.5\right)$ seems to offer satisfactory corrosion protection for carbon steel based on visual observations (Figure 13a). According to mass loss measurements the corrosion rate for the control is $0.138 \mathrm{~mm} /$ year whereas that for $\mathbf{M g}-\left(p-\mathbf{H}_{6} \mathbf{L}\right)$ is $0.067 \mathrm{~mm} /$ year $(\sim 51 \%$ inhibition $)$, with comparable efficiency to the $\mathrm{Zn}-\left(p-\mathrm{H}_{6} \mathrm{~L}\right)$ derivative.

An additional set of corrosion testing was carried out at $\mathrm{pH}$ 5.0. Corrosion rates are expected to be lower, as the solution $\mathrm{pH}$ increases. ${ }^{36}$ In the presence of ligand $p-\mathrm{H}_{8} \mathrm{~L}$ alone (no metal ions present), the inhibition efficiency is $0.075 \mathrm{~mm} /$ year $(\sim 34 \%)$. For the $\mathbf{M g}-\left(\boldsymbol{p}-\mathrm{H}_{6} \mathrm{~L}\right)$ material $\left(\right.$ at $\left[\mathrm{Mg}^{2+}\right]:\left[\mathrm{H}_{8} \mathrm{~L}\right]=$ $1: 1)$ the results show enhanced efficiency at this $\mathrm{pH}$ value, considering that the corrosion rate for the control is $0.113 \mathrm{~mm} /$ year, whereas that for $\mathbf{M g}-\left(\boldsymbol{p}-\mathbf{H}_{6} \mathbf{L}\right)$ is $0.021 \mathrm{~mm} /$ year $(\sim 81 \%)$, Figure $13 \mathrm{~b}$.

A preliminary set of studies done on the $\mathbf{Z n}-\left(p-\mathbf{H}_{6} \mathbf{L}\right)$ anticorrosion film at $\mathrm{pH} 2.5$. EDS showed a $\mathrm{Zn}: \mathrm{P}$ ratio of $\sim 1: 4$. The FT-IR spectrum of the film shows a good agreement with

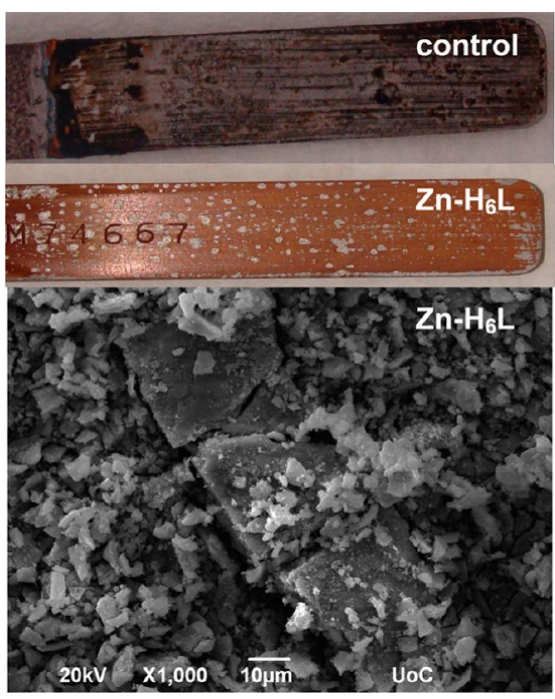

Figure 12. Anticorrosive effect of $\mathbf{Z n}-\left(p-\mathrm{H}_{6} \mathrm{~L}\right)$ precipitate on carbon steel at $\mathrm{pH}=2.2$. The upper specimen is the "control" (no inhibitor present). The lower specimen (in the middle) is protected by $\mathbf{Z n}-(p$ $\mathbf{H}_{6} \mathrm{~L}$ ) whose SEM is shown as well (at the bottom).

that of an authentic sample of $\mathbf{Z n}-\left(p-\mathbf{H}_{6} \mathbf{L}\right)$ (see Supporting Information Figure S17). Finally, the XRD powder patterns of both the $\mathbf{Z n}-\left(p-\mathbf{H}_{6} \mathrm{~L}\right)$ anticorrosion film at $\mathrm{pH} 2.5$ and $\mathrm{Zn}-(p$ $\mathbf{H}_{6} \mathbf{L}$ ) are essentially identical (Supporting Information Figure S18); however, the film shows poor crystallinity. This is a common phenomenon in metal phosphonate anticorrosion films. ${ }^{10,25 a, 27 a, 37}$

\section{CONCLUSIONS}

The principal conclusions derived from this work can be outlined as follows.

(1) Two families of isostructural hybrids were synthesized at either mild or hydrothermal conditions. These include compounds with the general formula $\mathrm{M}\left[\left(\mathrm{HO}_{3} \mathrm{PCH}_{2}\right)_{2} \mathrm{~N}\right.$ $\left.(\mathrm{H}) \mathrm{CH}_{2} \mathrm{C}_{6} \mathrm{H}_{4} \mathrm{CH}_{2} \mathrm{~N}(\mathrm{H})\left(\mathrm{CH}_{2} \mathrm{PO}_{3} \mathrm{H}\right)_{2}\left(\mathrm{H}_{2} \mathrm{O}\right)_{2}\right] \cdot 2 \mathrm{H}_{2} \mathrm{O}$ $(\mathrm{M}=\mathrm{Mg}, \mathrm{Co}$ and $\mathrm{Zn}), \mathbf{M}-\left(\boldsymbol{p}-\mathbf{H}_{6} \mathbf{L}\right)$, and $\mathrm{M}$ $\left[\left(\mathrm{H} \mathrm{O}_{3} \mathrm{PC} \mathrm{H}_{2}\right)_{2} \mathrm{~N}(\mathrm{H}) \mathrm{C} \mathrm{H}_{2} \mathrm{C}_{6} \mathrm{H}_{4} \mathrm{C} \mathrm{H}_{2} \mathrm{~N}(\mathrm{H})\right.$ $\left.\left(\mathrm{CH}_{2} \mathrm{PO}_{3} \mathrm{H}\right)_{2}\right] \cdot n \mathrm{H}_{2} \mathrm{O}(\mathrm{M}=\mathrm{Ca}, \mathrm{Mg}$, and $\mathrm{Zn}, n=1-1.5)$, $\mathbf{M}-\left(\boldsymbol{m}-\mathrm{H}_{6} \mathrm{~L}\right)$. Only the cobalt derivative of $\boldsymbol{m}-\mathrm{H}_{8} \mathrm{~L}$ was shown to present polymorphism.

(2) The basic structural feature of monodimensional $\mathbf{M}-(\boldsymbol{p}$ $\left.\mathbf{H}_{6} \mathrm{~L}\right)$ is an organic-inorganic chain, where the phosphonate moiety acts as a bidentate chelating ligand bridging two metal octahedra. $\mathbf{M}-\left(\boldsymbol{m}-\mathrm{H}_{\mathbf{6}} \mathbf{L}\right)$ exhibit a $3 \mathrm{D}$ pillared open-frameworks with channels containing uncoordinated water, the tetraphosphonate units acting simultaneously as bidentate and monodentate ligand.

(3) Conductivity values for representative samples of both families of compounds are within the range of other MOF-based water-mediated PCs. Although no significant differences in conductivity were appreciated, the activation energies found points to differences in the mechanism of proton transfer, attributed to variations in hydrogen bond networks for each structural archetype.

(4) The observed luminescence for derivatives $\mathbf{M g}-\left(p-\mathbf{H}_{6} \mathrm{~L}\right)$ and $\mathbf{Z n}-\left(p-\mathbf{H}_{6} \mathrm{~L}\right)$ is entirely ligand-based, with the slight change in $\lambda_{\max }$ in the emission spectra being accounted for by formation of anionic species, which slightly 

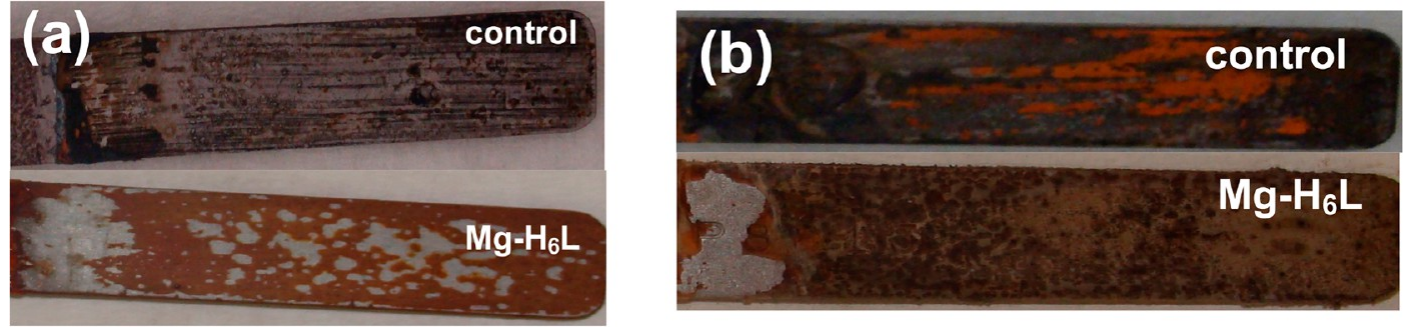

Figure 13. Anticorrosive effect of $\mathbf{M g}-\left(p-\mathrm{H}_{6} \mathrm{~L}\right)$ precipitate on carbon steel at (a) $\mathrm{pH} 2.5$ and (b) $\mathrm{pH} 5.0$. The upper specimen is the "control" (no inhibitor present). The lower specimen is protected by $\mathbf{M g}-\left(p-\mathrm{H}_{6} \mathrm{~L}\right)$.

perturb the electronic structure of the phosphonate ligand $p-\mathrm{H}_{8} \mathbf{L}$.

(5) Combinations of ligand $p-\mathrm{H}_{8} \mathrm{~L}$ and metal ions offer adequate protection to carbon steel surfaces at $\mathrm{pH} 2.5$, with enhanced inhibition efficiency at $\mathrm{pH}$ 5.0.

\section{ASSOCIATED CONTENT}

\section{S Supporting Information}

CIF files for $\mathbf{M}-\left(p-\mathbf{H}_{6} \mathbf{L}\right)$ and $\mathbf{M}-\left(\boldsymbol{m}-\mathbf{H}_{6} \mathbf{L}\right)$ compounds. Figures S1 and S2: Comparative PXRD patterns for Co- $(p-$ $\left.\mathbf{H}_{6} \mathbf{L}\right)$ and $\mathbf{M}-\left(m-\mathbf{H}_{6} \mathbf{L}\right)$ compounds. Figures S3 and S4: Rietveld plots for $\mathbf{M g}-\left(p-\mathrm{H}_{6} \mathrm{~L}\right)$ and $\mathrm{Zn}-\left(p-\mathrm{H}_{6} \mathrm{~L}\right)$. Figure S5: Detailed view of the H-bond interactions for $\mathrm{Zn}-\left(p-\mathbf{H}_{6} \mathrm{~L}\right)$. Figures S6 and S8: Rietveld plots for $\mathbf{M g}-\left(m-\mathrm{H}_{6} \mathrm{~L}\right)$ and $\mathbf{Z n}-$ $\left(m-\mathrm{H}_{6} \mathrm{~L}\right)$ at room temperature, and $\mathrm{Co}-\left(p-\mathbf{H}_{6} \mathrm{~L}\right)$ at $543 \mathrm{~K}$. Figures S9 and S10: Selected ball and stick and capped stick views for $\mathbf{C o}-\left(p-\mathrm{H}_{6} \mathrm{~L}\right)$ and $\mathrm{Co}-\left(m-\mathrm{H}_{6} \mathrm{~L}\right)$. Figure S11: Rietveld plots for $\mathbf{C o}-\left(m-\mathbf{H}_{6} \mathrm{~L}\right)$ at $573 \mathrm{~K}$. Figures $\mathrm{S} 12$ and S13: IR spectra for $\mathbf{M}-\left(p-\mathrm{H}_{6} \mathrm{~L}\right)$ and $\mathbf{M}-\left(m-\mathrm{H}_{6} \mathrm{~L}\right)$ compounds. Figure S14: Time dependence of $\log \sigma$ for $\mathbf{M g}-\left(p-\mathbf{H}_{6} \mathbf{L}\right)$ and $\mathbf{Z n}-(m-$ $\left.\mathbf{H}_{6} \mathbf{L}\right)$ at two RH values. Figures $S 15$ and S16: Complex impedance plane plots for $\mathbf{M g}-\left(p-\mathrm{H}_{6} \mathrm{~L}\right)$ and $\mathrm{Zn}-\left(m-\mathrm{H}_{6} \mathrm{~L}\right)$ at $69 \%$ RH. Figure S17: FTIR spectra of the $\mathbf{Z n}-\left(p-\mathbf{H}_{6} \mathbf{L}\right)$ anticorrosion film and that of an authentic sample. Figure S18: XRD powder patterns of the $\mathbf{Z n}-\left(p-\mathbf{H}_{6} \mathrm{~L}\right)$ anticorrosion film and that of an authentic sample. Table S1: Bond length and angles for $\mathbf{M}-\left(\boldsymbol{p}-\mathbf{H}_{6} \mathbf{L}\right)$ compounds. Table S2-S4: Selected Hbond interactions for $\mathbf{M}-\left(\boldsymbol{p}-\mathbf{H}_{6} \mathbf{L}\right)$ compounds. Table S5 and S6: Selected H-bond interactions for $\mathbf{M}-\left(m-\mathbf{H}_{6} \mathbf{L}\right)$ compounds. Table S7: Bond length and angles for $\mathrm{Co}-\left(p-\mathrm{H}_{6} \mathrm{~L}\right)$ at $473 \mathrm{~K}$. This material is available free of charge via the Internet at http://pubs.acs.org.

\section{AUTHOR INFORMATION}

\section{Corresponding Author}

*E-mail addresses: demadis@chemistry.uoc.gr (K.D.D.); aurelio@uma.es (A.C.).

\section{Notes}

The authors declare no competing financial interest.

\section{ACKNOWLEDGMENTS}

The work at UMA was funded by MAT2010-15175 research grant (Spain) which is cofunded by FEDER. The work at the UoC was supported by a grant from the Research Committee of the University of Crete, ELKE (KA 2573). ESRF is thanked for the provision of synchrotron X-ray beamtime at ID31 beamline.

\section{REFERENCES}

(1) (a) Special thematic issue on Metal Organic Frameworks. Chem. Rev. 2012, 112, 673-1268. (b) Special Thematic Issue on Hybrid Materials. Chem. Soc. Rev. 2011, 40, 453-1152. (c) Themed issue on Coordination chemistry in the solid state. Dalton Trans. 2012, 41, 3845-4264. (d) Jiang, H.-L.; Xu, Q. Chem. Commun. 2011, 47, 33513370. (e) Meek, S. T.; Greathouse, J. A.; Allendorf, M. D. Adv. Mater. 2011, 23, 249-267. (f) Themed issue on Metal-Organic Frameworks. Chem. Soc. Rev. 2009, 38, 1201.

(2) (a) Functional Metal-Organic Frameworks: Gas Storage, Separation and Catalysis. In Topics in Current Chemistry; Schröder., M., Ed.; Springer: New York, 2010; Vol. 293. (b) Metal organic frameworks: Design and application; Macgillivray, L. R., Ed.; Wiley: New York, 2010. (c) Metal-Organic Frameworks. Applications from Catalysis to Gas Storage; Farrusseng, D., Ed.; Wiley-VCH Verlag \& Co. KGaA: Weinheim, Germany, 2011.

(3) (a) Colodrero, R. M. P.; Papathanasiou, K. E.; Stavgianoudaki, N.; Olivera-Pastor, P.; Losilla, E. R.; Aranda, M. A. G.; León-Reina, L.; Sanz, J.; Sobrados, I.; Choquesillo-Lazarte, D.; García-Ruiz, J. M.; Atienzar, P.; Rey, F.; Demadis, K. D.; Cabeza, A. Chem. Mater. 2012, 24, 3780. (b) Bazaga-Garcia, M.; Cabeza, A.; Olivera-Pastor, P.; Santacruz, I.; Colodrero, R. M. P. J. Phys. Chem. C 2012, 116, 1452614533. (c) Gómez-Alcántara, M. M.; Cabeza, A.; Olivera-Pastor, P.; Fernández-Moreno, F.; Sobrados, I.; Sanz, J.; Morris, R. E.; Clearfield, A.; Aranda, M. A. G. Dalton Trans. 2007, 2394-2404.

(4) (a) Taddei, M.; Costantino, F.; Ienco, A.; Comotti, A.; Dau, P. V.; Cohen, S. Chem. Commun. 2013, 49, 1315-1317. (b) Costantino, F.; Donnadio, A.; Casciola, M. Inorg. Chem. 2012, 51, 6992-7000. (c) Wharmby, M.; Mowat, M. T.; John, P. S.; Thompson, S. P.; Wright, P. A. J. Am. Chem. Soc. 2011, 133, 1266-1269. (d) Colodrero, R. M. P.; Cabeza, A.; Olivera-Pastor, P.; Papadaki, M.; Rius, J.; Choquecillo-Lazarte, D.; García-Ruiz, J. M.; Demadis, K. D.; Aranda, M. A. G. Crys. Growth Des. 2011, 11, 1713-1722. (e) Yang, C.-I.; Song, Y.-T.; Yeh, Y.-J.; Liu, Y.-H.; Tseng, T.-W.; Lu, K.-L. CrystEngComm 2011, 13, 2678-2686. (f) Attfield, M. P.; Yuan, Z.; Harvey, H. G.; Clegg, W. Inorg. Chem. 2010, 49, 2656-2666. (g) Taddei, M.; Costantino, F.; Vivani, R. Inorg. Chem. 2010, 49, 9664-9670. (h) Colodrero, R. M. P.; Cabeza, A.; Olivera-Pastor, P.; Infantes-Molina, A.; Barouda, E.; Demadis, K. D.; Aranda, M. A. G. Chem.-Eur. J. 2009, 15, 6612-6618.

(5) Metal phosphonate chemistry: From synthesis to applications; Clearfield, A., Demadis, K. D., Eds.; The Royal Society of Chemistry: London, 2012.

(6) (a) Yoon, M.; Suh, K.; Natarajan, S.; Kim, K. Angew. Chem., Int. Ed. 2013, 52, 2688-2700. (b) Liang, X.; Zhang, F.; Feng, W.; Zou, X.; Zhao, C.; Na, H.; Liu, C.; Sun, F.; Zhu, G. Chem. Sci. 2013, 4, 983992. (c) Shimizu, G. K. H.; Taylor, J. M.; Dawson, K. W. In Metal phosphonate chemistry: From synthesis to applications; Clearfield, A. Demadis, K. D., Eds.; The Royal Society of Chemistry: London, 2012; Chapter 15, p 493. (d) Jeong, N. C.; Samanta, B.; Lee, C. Y.; Farha, O. K.; Hupp, J. T. J. Am. Chem. Soc. 2012, 134, 51-54. (e) Colodrero, R. M. P.; Olivera-Pastor, P.; Losilla, E. R.; Aranda, M. A. G.; León-Reina, L.; Papadaki, M.; McKinlay, A. C.; Morris, R. E.; Demadis, K. D.; Cabeza, A. Dalton Trans. 2012, 41, 4045-4051. (f) Colodrero, R. M. P.; Olivera-Pastor, P.; Losilla, E. R.; Hernández-Alonso, D.; Aranda, M. 
A. G.; León-Reina; Rius, J.; Moreau, B.; Demadis, K. D.; Villemin, D.; Palomino, M.; Rey, F.; Cabeza, A. Inorg. Chem. 2012, 51, 7689-7698. (g) Sadakiyo, M.; Okawa, H.; Shigematsu, A.; Ohba, M.; Yamada, T.; Kitagawa, H. J. Am. Chem. Soc. 2012, 134, 5472-5475. (h) Sadakiyo, M.; Yamada, T.; Kitagawa, H. J. Am. Chem. Soc. 2009, 131, 99069907. (i) Hurd, J. A.; Vaidhyanathan, R.; Thangadurai, V.; Ratcliffe, C. I.; Moudra-kovski, I. M.; Shimizu, G. K. H. Nat. Chem. 2009, 1, 705710. (j) Sahoo, S. C.; Kundu, T.; Banerjee, R. J. Am. Chem. Soc. 2011, 133, 17950-17958. (k) Shigematsu, A.; Yamada, T.; Kitagawa, H. J. Am. Chem. Soc. 2011, 133, 2034-2036.

(7) Kim, S.; Dawson, K. W.; Gelfand, B. S.; Taylor, J. M.; Shimizu, G. K. H. J. Am. Chem. Soc. 2013, 135, 963-966.

(8) Ponomareva, V. G.; Kovalenko, K. A.; Chupakhin, A. P.; Dybtsev, D. N.; Shutova, E. S.; Fedin, V. P. J. Am. Chem. Soc. 2012, 134, 1564015643.

(9) (a) Sekine, I.; Shimode, T.; Yuasa, M. Ind. Eng. Chem. Res. 1992, 31, 434-439. (b) Mosayebi, B.; Kazemeini, M.; Badakhshan, A. Br. Corr. J. 2002, 37, 217-224. (c) Kouznetsov, Yu.I. Prot. Met. 2001, 37, 434-439. (d) Balaban-Irmenin, Yu. V.; Rubashov, A. M.; Fokina, N. G. Prot. Met. 2006, 42, 133-136. (e) Fang, J. L.; Li, Y.; Ye, X. R.; Wang, Z. W.; Liu, Q. Corrosion 1993, 49, 266-271. (f) Paszternák, A.; Stichleutner, S.; Felhősi, I.; Keresztes, Z.; Nagy, F.; Kuzmann, E.; Vértes, A.; Homonnay, Z.; Pető, G.; Kálmán, E. Electrochim. Acta 2007, 53, 337-345. (g) Marin-Cruz, J.; Cabrera-Sierra, R.; Pech-Canul, M. A.; Gonzalez, I. Electrochim. Acta 2006, 51, 1847-1854.

(10) (a) Demadis, K. D.; Mantzaridis, C.; Raptis, R. G.; Mezei, G. Inorg. Chem. 2005, 44, 4469-4471. (b) Demadis, K. D.; Katarachia, S. D.; Koutmos, M. Inorg. Chem. Commun. 2005, 8, 254-258. (c) Demadis, K. D.; Lykoudis, P.; Raptis, R. G.; Mezei, G. Cryst. Growth Des. 2006, 6, 1064-1067. (d) Demadis, K. D.; Mantzaridis, C.; Lykoudis, P. Ind. Eng. Chem. Res. 2006, 45, 7795-7800.

(11) (a) Hix, G. B. In Metal phosphonate chemistry: From synthesis to applications; Clearfield, A., Demadis, K. D., Eds.; The Royal Society of Chemistry: London, 2012; Chapter 16, p 525-550. (b) Rocha, J.; Carlos, L. D.; Almeida Paz, F. A.; Ananias, D. Chem. Soc. Rev. 2011, 40, 926-940. (c) Tang, S.-F.; Pan, X.-B.; Lv, X.-X.; Zhao, X.-B. J. Solid State Chem. 2013, 197, 139-146. (d) Rao, X. T.; Huang, Q.; Yang, X. L.; Cui, Y. J.; Yang, Y.; Wu, C. D.; Chen, B. L.; Qian, G. D. J. Mater. Chem. 2012, 22, 3210-3214.

(12) Angeli, G.; Cabeza, A.; Villemin, D.; Aranda, M. A. G.; Demadis, K. D. Synthesis of Aminomethylene Tetraphosphonic Acids and Their Inorganic-Organic Hybrid Compounds. Congrès MATERIAUX 2010; Palais des Congrès de Nantes, France, October 18-22, 2010.

(13) Villemin, D.; Moreau, B.; Elbilali, A.; Didi, M.-A.; Kaid, M.; Jaffrès, P.-A. Phosphorus Sulfur Silicon 2010, 185, 2511-2519.

(14) Colodrero, R. M. P.; Olivera-Pastor, P.; Cabeza, A.; Papadaki, M.; Demadis, K. D.; Aranda, M. A. G. Inorg. Chem. 2010, 49, 761-768.

(15) Boultif, A.; Louer, D. J. Appl. Crystallogr. 2004, 37, 724-731.

(16) Altomare, A.; Camalli, M.; Cuocci, C.; Giacovazzo, C.; Moliterni, A.; Rizzi, R. J. Appl. Crystallogr. 2009, 42, 1197-1202.

(17) Rietveld, H. M. J. Appl. Crystallogr. 1969, 2, 65-71.

(18) Larson, A. C.; Von Dreele, R. B. General Structure Analysis System (GSAS); Los Alamos National Laboratory: Los Alamos, NM, 2004; Report LAUR 86-748.

(19) Toby, B. H. J. Appl. Crystallogr. 2001, 34, 210-213.

(20) winDETA; Novocontrol GmbH: Hundsangen, Germany, 1995.

(21) NACE Standard TM0169-95 (Item No. 21200), National Association of Corrosion Engineers, Houston TX, U.S.A., 1995; www.nace.org.

(22) Stock, N.; Stoll, A.; Bein, T. Microporous Mesoporous Mater. 2004, 69, 65-69.

(23) (a) Stock, N.; Bein, T. Angew. Chem., Int. Ed. 2004, 43, 749752. (b) Stock, N.; Rauscher, M.; Bein, T. J. Solid State Chem. 2004, 177, 642-647. (c) Zheng, G.-L.; Ma, J.-F.; Yang, J. J. Chem. Res. 2004, $387-388$.

(24) (a) Socrates, G. Infrared and Raman Characteristic Group Frequencies: Tables and Charts; John Wiley \& Sons: Chichester, 2001. (b) Taddei, M.; Costantino, F.; Vivani, R. Inorg. Chem. 2010, 49, 9664-9670.
(25) (a) Demadis, K. D.; Barouda, E.; Raptis, R. G.; Zhao, H. Inorg. Chem. 2008, 48, 819-821. (b) Barouda, E.; Demadis, K. D.; Freeman, S.; Jones, F.; Ogden, M. I. Cryst. Growth Des. 2007, 7, 321-327.

(26) Costantino, F.; Bataille, T.; Audebrand, N.; Fur, E.; Sangregorio, C. Cryst. Growth Des. 2007, 7, 1881-1888.

(27) (a) Demadis, K. D.; Barouda, E.; Stavgianoudaki, N.; Zhao, H. Cryst. Growth Des. 2009, 9, 1250-1253. (b) Akyol, E.; Öner, M.; Barouda, E.; Demadis, K. D. Cryst. Growth Des. 2009, 9, 5145-5154.

(28) Katarachia, S. D.; Demadis, K. D. Phosphorus Sulfur Silicon 2004, 179, 627-648.

(29) (a) Taylor, J. M.; Mah, R. K.; Moudrakovski, I. L.; Ratcliffe, C. I.; Vaidhyanathan, R.; Shimizu, G. K. H. J. Am. Chem. Soc. 2010, 132, 14055-14057. (b) Taylor, J. M.; Dawson, K. W.; Shimizu, G. K. H. J. Am. Chem. Soc. 2013, 135, 1193-1196.

(30) Costantino, F.; Donnadio, A.; Casciola, M. Inorg. Chem. 2012, $51,6992-7000$.

(31) Colomban, P. Proton Conductors: Solids, Membranes and Gels Materials and Devices. Chemistry of Solid State Materials; Cambridge University Press, Cambridge, U.K., 1992; Vol. 2.

(32) Dippel, T.; Kreuer, K. D. Solid State Ionics 1991, 46, 3-9.

(33) Kreuer, K. D. Solid State Ionics 2000, 136, 149-160.

(34) Kreuer, K. D.; Weppner, W.; Rabenau, A. Mater. Res. Bull. 1982, 17, 501-509.

(35) Singleton, R.; Bye, J.; Dyson, J.; Baker, G.; Ranson, R. M.; Hix, G. B. Dalton Trans. 2010, 39, 6024-6030.

(36) Demadis, K. D.; Stavgianoudaki, N. In Metal phosphonate chemistry: From synthesis to applications; Clearfield, A.; Demadis, K. D., Eds.; The Royal Society of Chemistry: London, 2012; Chapter 14, p 438-469.

(37) (a) Demadis, K. D.; Papadaki, M.; Raptis, R. G.; Zhao, H. J. Solid State Chem. 2008, 181, 679-683. (b) Demadis, K. D.; Papadaki, M.; Raptis, R. G.; Zhao, H. Chem. Mater. 2008, 20, 4835-4846. (c) Papadaki, M.; Demadis, K. D. Comments Inorg. Chem. 2009, 30, 89-118. (d) Demadis, K. D.; Papadaki, M.; Varouchas, D. In Green Corrosion Chemistry and Engineering: Opportunities and Challenges; Sharma, S. K., Ed.; Wiley-VCH Verlag GmbH \& Co., Germany, 2012; Chapter 9, pp 243-296. (e) Demadis, K. D.; Katarachia, S. D.; Koutmos, M. Inorg. Chem. Commun. 2005, 8, 254-258.

\section{NOTE ADDED IN PROOF}

While this paper was in press, an article appeared "Highthroughput microwave-assisted discovery of new metal phosphonates", Feyand, M.; Seidler, C. F.; Deiter, C.; Rothkirch, A.; Lieb, A.; Wark, M.; Stock, N. Dalton Trans. 2013, 42, 8761-8770. The article describes syntheses and structural chemistry of six metal ions $\left(\mathrm{Ca}^{2+}, \mathrm{Mn}^{2+}, \mathrm{Co}^{2+}, \mathrm{Ni}^{2+}\right.$, $\mathrm{Zn}^{2+}$, and $\mathrm{Cd}^{2+}$ ) with the ligands $p-\mathrm{H}_{8} \mathrm{~L}$ and $m-\mathrm{H}_{8} \mathrm{~L}$. 